\title{
Detecting multiscale karst features including hidden caves using microgravimetry in a Caledonian nappe setting: Mefjell massif, Norway
}

\author{
Terje Solbakk', Christine Fichler', Walter Wheeler², Stein-Erik Lauritzen ${ }^{3}$ \\ \& Philip Ringrose ${ }^{1}$
}

${ }^{1}$ Department of Geoscience and Petroleum, Norwegian University of Science and Technology (NTNU), Sem Salands veg 1, 7491, Trondheim, Norway.
${ }^{2}$ Uni Research CIPR, Nygårdsgaten 112, 5007 Bergen, Norway

${ }^{3}$ Department of Earth Science, University of Bergen, Allégaten 41, 5007 Bergen, Norway.

E-mail corresponding author (Terje Solbakk): terje.solbakk@ntnu.no

Cave passages and karst features form negative density contrasts expressed in gravity field anomalies. We present an interpretation approach for microgravimetry, applicable for challenging geological settings with heterogeneous lithologies. The workflow covers not only detection of large cave rooms, but also deals with minor karst features (epikarst) in carbonate rocks. Challenges due to heterogeneous infill of large cavities and variations in carbonate facies are addressed. We used 3D forward modelling of surface gravity measurements to investigate a large karst cave complex, known as the Svarthammarhola cave, in the Caledonian nappe setting of Nordland. The most important result relates to distinct gravity lows detected in the survey, which are interpreted as hitherto unknown and inaccessible cave rooms, some of them of a very large size. These correspond with known collapse and sediment infill features both at the surface and inside the Svarthammarhola cave system. This expands the known cave in an eastward and northward direction.

Combining the cave's position at the top of the hinge of a large antiform where we also modelled uncommonly high densities, together with the cave's outstanding size, opens for new interpretations of the speleogenesis of the Svarthammarhola cave. The study also has wider implications on how gravity field data can be used for the understanding of complex subsurface karst features.

Keywords: gravity acquisition, gravity interpretation, cave detection, microgravity, karst

Received 12. February 2018 / Accepted 7. July 2018 / Published online 20. November 2018

\section{Introduction}

Karst describes a suite of surface and subsurface landforms developed through chemical dissolution of soluble bedrock, of which carbonates are the commonest. Dissolution increases the amount of secondary porosity of the rock mass on a wide range of scales, leading to a decrease of surface drainage, underground caves, streams and sinks, springs and surface expressions characterised by undermining, forming dolines of various kind. Further evolution may lead to extensive collapses and disjunction from the contemporary hydrological system, forming paleokarst. 'Karst porosity' is therefore a combination of chemical (dissolution) and mechanical (collapse) processes. The karst terms used here refer to the textbook of Ford \& Williams (2007). Dolines, in a larger sense, can be related to collapse, sag and subsidence by chemical and/or mechanical breakdown. Epikarst describes the weathered and fractured three to ten uppermost metres of the karstified rock, and its characteristics may vary extensively (Ford \& Williams, 2007). Although the epikarst zone often has a scattered distribution, epikarst can be found over several square kilometres in lateral

Solbakk, T., Fichler, C., Wheeler, W., Lauritzen, S.-E. \& Ringrose, P. 2018: Detecting multiscale karst features including hidden caves using microgravimetry in a Caledonian nappe setting: Mefjell massif, Norway. Norwegian Journal of Geology 98, 359-378.

https://dx.doi.org/10.17850/njg98-3-04. 

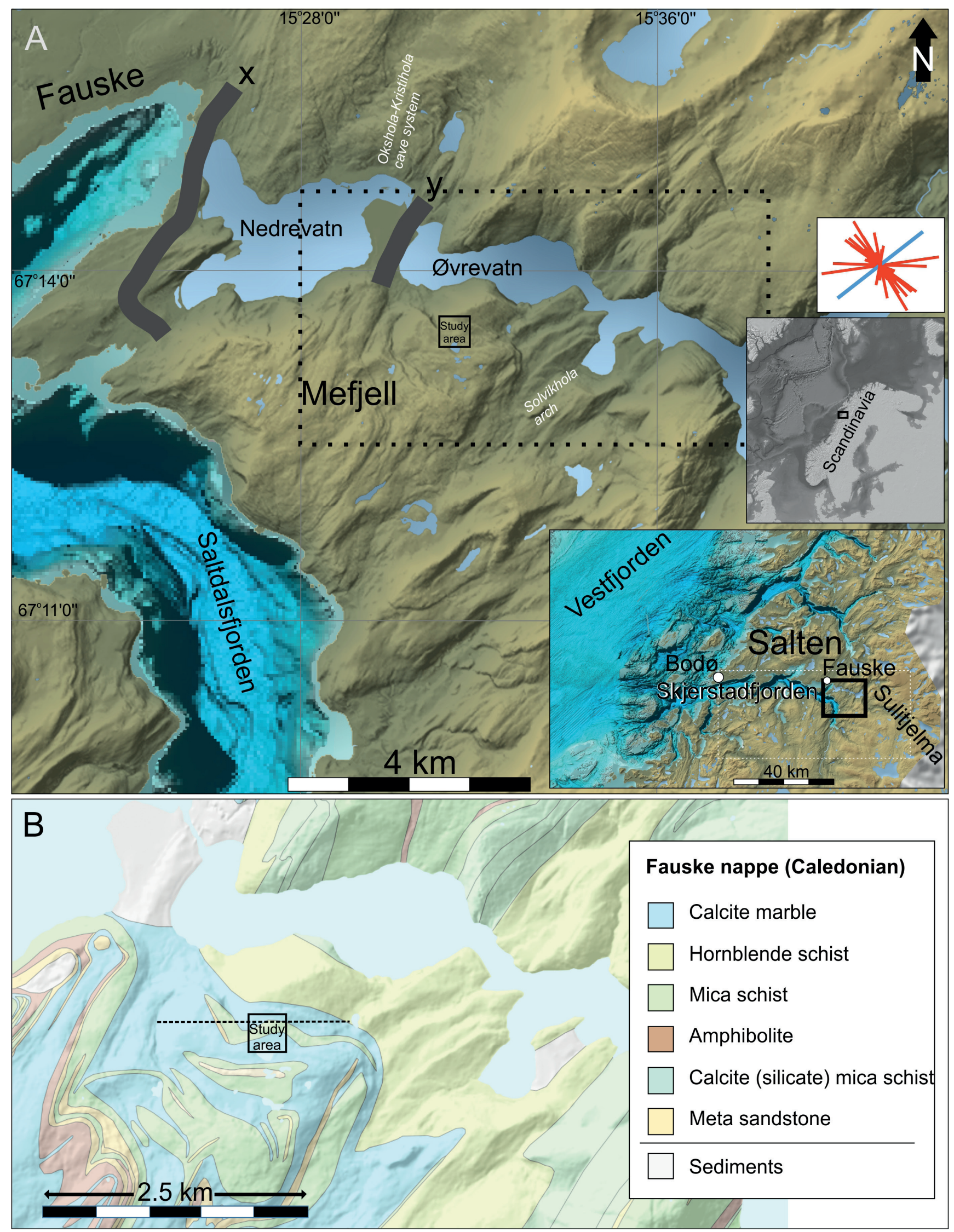

Figure 1. (A) Topographic map of the greater Mefjell massif with 'Study area' shown in detail in Fig. 4, (www.kartverket.no, accessed 01.02.2018). Stippled box marks location of the geological map shown in (B), features $X$ and $Y$ are end moraines (Andersen, 1975). Main lineament trends (red, in the inset, top right) interpreted from topography map within the (B) frame, with main foliation trend (blue) derived from the geological map in (B), with normalised trend line length. (B) Geological map; the stippled line refers to Fig. $15 B$. 
extension. In a glaciated setting, the epikarst zone may be complete or partly removed.

We look closer into the area around the Svarthammarhola cave (SHC), located in the Mefjell massif of Nordland, northern Norway (Fig. 1A), which is the largest cave volume found in Scandinavia as described below in more detail. In our study area we encounter typical largescale (more than a few metres width and height) karst landforms such as caves, dolines and epikarst.

Caves can be accessible to man, and surveyed by means of compass, clinometer and distance tools of different kinds. These data usually just document the existence of, and provide some basic information about the caves, but do not necessarily give details of all existing cave rooms or geological features within the cave and rock mass. However, human exploration is strongly biased; a cave map is always a minimum estimate of the void porosity. Indications of hidden, inaccessible cave passages can be deduced from cave surveying and inspection. Examples include: descriptions of rock shelters with collapsed back wall next to known cave systems, sag depressions on the land surface above the cave, choked dolines or vertical pipes, and sediment-choked passages or water-filled passages. However, an estimate of the extension and geometry of hidden cave rooms requires either physically entering the cave system or by using remote geophysical mapping methods, as described here.

The subsurface density is directly expressed in gravity data, and therefore gravimetric exploration can be a valuable method for detection of karst porosity and hidden caves. The main challenge for gravimetric mapping of karstified rock formations is that the changes in density occur over a wide range of scales due to the chemical dissolution process and the complexity created by subsequent infill (by air, water or sediment).

Several papers have demonstrated the use of gravity measurements as an aid to find natural and manmade cavities; either as a standalone method, or combined with other geophysical methods, or by invasive techniques such as drilling or entering the cave. Chico (1964) was the first to go into detail on detection of caves by gravimetry, and referred to earlier work pointing to such possibilities. Later, Butler (1984), Barrows \& Fett (1985), Styles et al. (2005), Ardestani (2008), Martinez-Moreno et al. (2014), Braitenberg et al. (2016) and Kaufmann et al. (2015) showed examples of successfully detecting karst caves, some supported also by other geophysical methods like resistivity imaging and self-potential surveying (Kaufmann et al., 2015) or by drilling (Barrows \& Fett, 1985; Ardestani, 2008). However, at times, inconclusive results were reported due to the inherent ambiguity in gravimetric exploration; for example, Kaufmann \& Romanov (2009) described a case where the gravimetry data could not distinguish between a buried doline and a cave. Epikarst has generally not been considered in earlier work applying gravity data to karst cave exploration.
To our knowledge, gravity measurements have not been used for karst cave exploration in Norway, and the results should therefore be of value to understanding the local karstic geology as well as buried karst systems in general. The SHC provides an excellent opportunity to explore a large cave system on all scales.

Fig. 2 shows the amplitude of the gravity anomaly of an open sphere and a horizontal cylinder within a rock mass, calculated with formulas from Chico (1964), demonstrating that the gravity response decreases with depth. A cylinder at a depth of $250 \mathrm{~m}$ produces only a $1 / 100^{\text {th }}$ of the anomaly produced if at a depth of $10 \mathrm{~m}$, documenting that the most dominant anomalies relate to sources in the uppermost subsurface. The depth of the SHC, marked in Fig. 2, indicates that a cave room with the size of the SHC should be detectable more than some tens of metres below the surface. Another effect of an increasingly greater depth down to the void is an increasing wavelength. The SHC is positioned at a depth where the details of the cave passage geometry disappear into smooth long-wavelength anomalies. This indicates that shallower cave rooms, if they exist, will dominate the gravity signal. A further challenge is that the gravity signal of the cave room is superimposed on the gravity signal from host-rock heterogeneities.

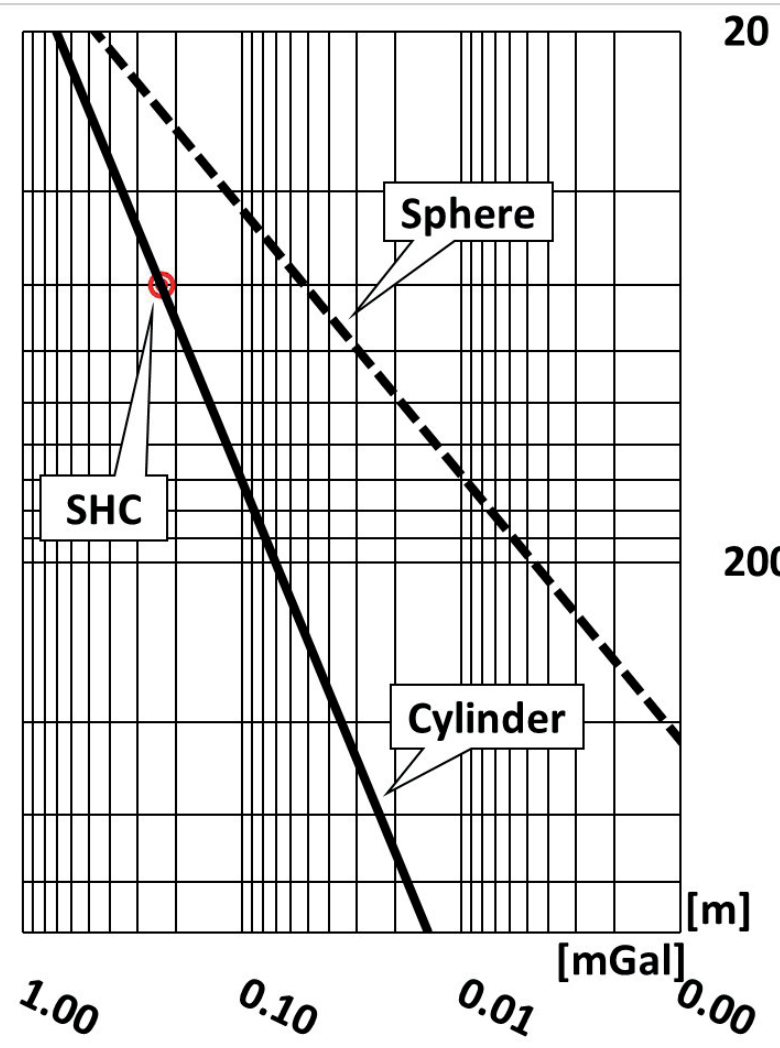

Figure 2. The modelled maximal gravity anomaly size of a sphere (dashed line) and a horizontal cylinder, both with a radius of 20 metres, buried at various depths with density contrast $2770 \mathrm{~kg} /$ $\mathrm{m}^{3}$. Y-axis shows depth to centre of sphere/cylinder. Known cave indicated (red circle). SHC - Svarthammarhola cave. 
The aim of this paper is to use microgravimetry to investigate the geometry of hidden cave passages believed to be a continuation of the SHC, and the distribution of multiscale karst features. This study demonstrates the potential for near-surface mapping and discusses the potential for application in hydrological or petroleum exploration studies. Finally, we discuss implications for the speleogenesis of the SHC.

\section{Geological setting}

\section{Regional geology, geomorphology and glacial geology}

The bedrock of the central part of Nordland County can be characterised as mainly comprising Caledonian folded metasedimentary rocks (Roberts et al., 2002) of Laurentian origin, resting on older (autochthonous) metasedimentary and crystalline basement rocks. The Caledonian rocks are divided into several nappes, and the Mefjell massif is situated within the Fauske Nappe. This nappe belongs to either the Upper or the Uppermost Allochthon (Drivenes et al., 2016); ages are disputed, but Roberts et al. (2002) argued for an Early Cambrian age. From the topography and bedrock map (www.ngu.no/emne/kartinnsyn accessed 01.02.2018; Fig. 1A, B; Kollung \& Gustavson, 1995) the structural setting of the eastern part of the Mefjell massif can be described as mainly comprising a NNE-SSW-trending antiform. The antiform's core is composed of hornblende schist of the Håskolt Formation, and is partly conglomeratic. It is overlain by calcite marble belonging to the Rognan Formation, which again is overlain by, and interfingered with, mica schist of the Langvad Formation of the Pålsfjell Group together with quartzite of the Pothus Formation. Amphibolite is also found interfingering with the mica schist. The Caledonian nappes were transported in an east-southeasterly direction over Proterozoic metamorphosed granitic gneisses (referred to as Krågakomplekset), younger mica schist and metaarkose. Intrusions of Meso- to early Neoproterozoic plutonic rocks within the nappes, earlier assigned to Cambro-Silurian ages, are also found in the vicinity (Agyei-Dwarko et al., 2012).

The greater Salten area is dominated by a major fjord system, Saltfjorden, incised in an undulating peneplain found at altitudes between $\sim 400$ and $1000 \mathrm{~m}$ a.s.l. with mountain massifs reaching slightly over $1900 \mathrm{~m}$ a.s.l. (Lidmar-Bergstrøm et al., 2007).

The Nordland area was repeatedly glaciated and heavily eroded throughout the Quaternary period (Mangerud, 2004). Quaternary glacial erosion has removed most post-Caledonian rocks and geomorphologically severely modified, enhanced and/or over-deepened the relief leading to an extensive fjord development, glacifluvial canyons and glacially-derived deposits (Fig. 1A; Andersen, 1975). Glaciers still exist some kilometres away from the cave area, but their glacial drainage does not affect the Mefjell massif or bring glacial water into our study area. Several cirque forms can be observed in the topography around and at the Mefjell massif. Evidence for a stagnant ice mass in the SHC area may indicate a relict glacier (see SHC description below for details). Pronounced fjord features and cirques are also developed together with the deposition of large amounts of glacial deposits in the areas of lower elevation. During the last glacial maximum, the general ice movement was towards the NW (Andersen, 1975). Deglaciation led to further development of the relief-controlled ice flow from the remaining ice sheet, following the topographic lows of valleys and fjords. In the vicinity of the cave, two end moraines are recognised along the Nedrevatn/Øvrevatn valley (Fig. 1A): the Finneid and the younger Øvrevann end moraines. These end moraines are assigned to a Pre-Boreal age and thus give a minimum age for icefree conditions at the cave plateau. A radiocarbon age of $8760 \pm 150$ years B.P. has been reported for shells found in marine silt and clays overlying the moraine, giving a minimum age for the Finneid end moraine (Andersen, 1975). Shells from assumed contemporary marine layers deposited in front of the Finneid moraine ridge were dated to $9570 \pm 150$ years B.P.. Thin or scattered sediments cover the study area.

The post-glacial marine limit is modelled to have reached about $150 \mathrm{~m}$ above present-day sea level (www.ngu.no/ accessed 01.12.2018) which reaches the elevation of the lowest surveyed passage in the SHC. However, marine sediments have not been observed within the cave. Caves can generally act as sediment traps under glacial conditions, but limited accommodation space and flush episodes by glacial meltwater, or freeze/thaw cycles within the cave, can lead to very scattered sediment packages of uncertain origin (e.g., Valen et al., 1997; Fedje, 2006; Ford \& Williams, 2007). Later flooding events may also erode and redeposit cave sediments. Glacial erosion may also have eroded former epikarst zones.

\section{The cave system Svarthammarhola (SHC)}

Scientific exploration of caves in Norway has taken place since the 1800s, and more systematically since the $1960 \mathrm{~s}$ (Lauritzen, 2010). Most Scandinavian karst caves are of a minor volume (Lauritzen, 2010), with cave room dimensions of typically 1-2 metres modal width. The caves are usually described and quantified in terms of height, length and width upon surveying. More than 40 caves in Norway have dimensions of more than $1 \mathrm{~km}$ in cave passage length (www.speleo.no/dannelse/index.htm accessed 01.11.2018; Lauritzen et al., 2005; Skoglund \& Lauritzen, 2010). The SHC system (Lauritzen et al., 2005) 
is situated at the northern part of the Mefjell massif, beneath a plateau next to the fjord valley Øvrevatn and SSE of the town of Fauske (Fig. 1A). The main passage chamber (Figs. $3 \& 4$ ) covers an area of approximately $40,000 \mathrm{~m}^{2}$, reaching more than $100 \mathrm{~m}$ in width and several hundred metres in length, and is connected with smaller cave passages (Lauritzen \& Mihevc, 2015). This passage chamber encompasses the largest volume of a cave room measured in Norway. The cave was discovered in 1969 by local cavers and published in a newspaper article (Andreassen, 1969), and the first map was produced in the following year (Heap, 1970). The SHC was resurveyed in several field campaigns throughout 2005-07 (Lauritzen, 2010), and work is still ongoing. Using compass, clinometer and laser distance- meter, aiming for $\pm 1 \mathrm{~cm}$ and $\pm 1^{\circ}$ precision, vectors were measured from stations to stations, established throughout the cave passages, and on the land surface to connect to other smaller caves in the area. From selected stations within the main cave passages, more detailed vertical profiles of the roof and wall were created by measuring distance to the cave perimeter every $0.5-1^{\circ}$. This procedure may lead to uncertainties in positioning the cave in the rock mass beneath the plateau. Measurements were treated as polygon lines and imported into vector software Grottolf for cave visualisation (Lauritzen, 2008), and a coarse wall map for the main passages of the SHC is presented in Figs. 3 \& 4. We used these data to construct top and bottom surfaces of the SHC, simplified for gravity modelling purposes.
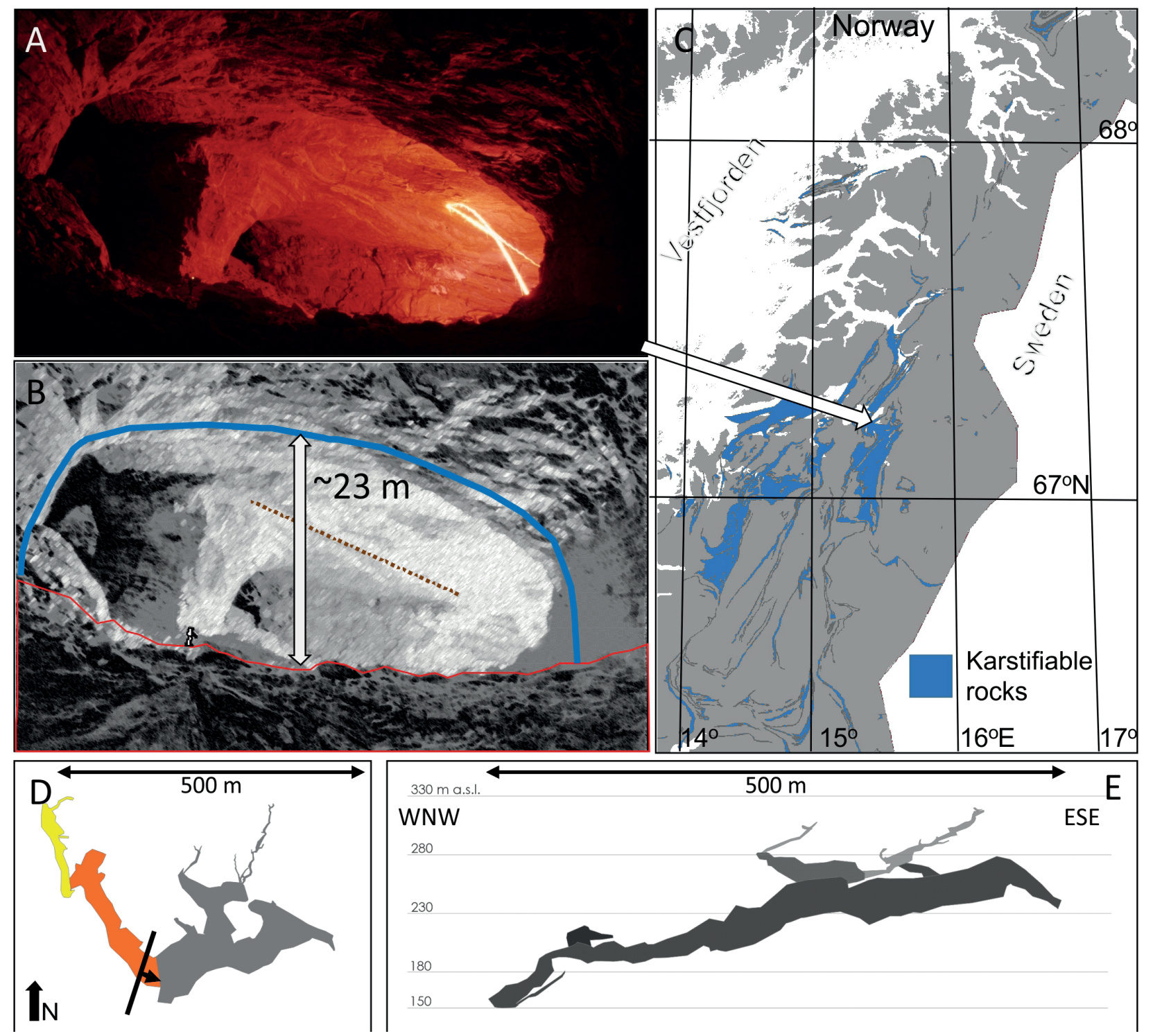

Figure 3. (A) shows a profile along a typical cave passage in the SHC and associated collapse sediment floor; for location of profile, see (D). (B) shows an outline of the same cave passage, with blue line marking cave passage roof and wall, and red polygon indicating sediments, stippled line marks foliation trend. (C) Map with major units of karstifiable rocks shown in blue colour (www.ngu.no/ and www.geonorge.no, accessed 01.12.2017). (D) shows horizontal outline of cave passages, lowermost part of cave (yellow), and area of ice mass occurrence (orange). (E) shows a stacked profile view with all SHC passages, the main passage in darkest grey. SHC drawn from data compiled and provided by S.-E. Lauritzen. 


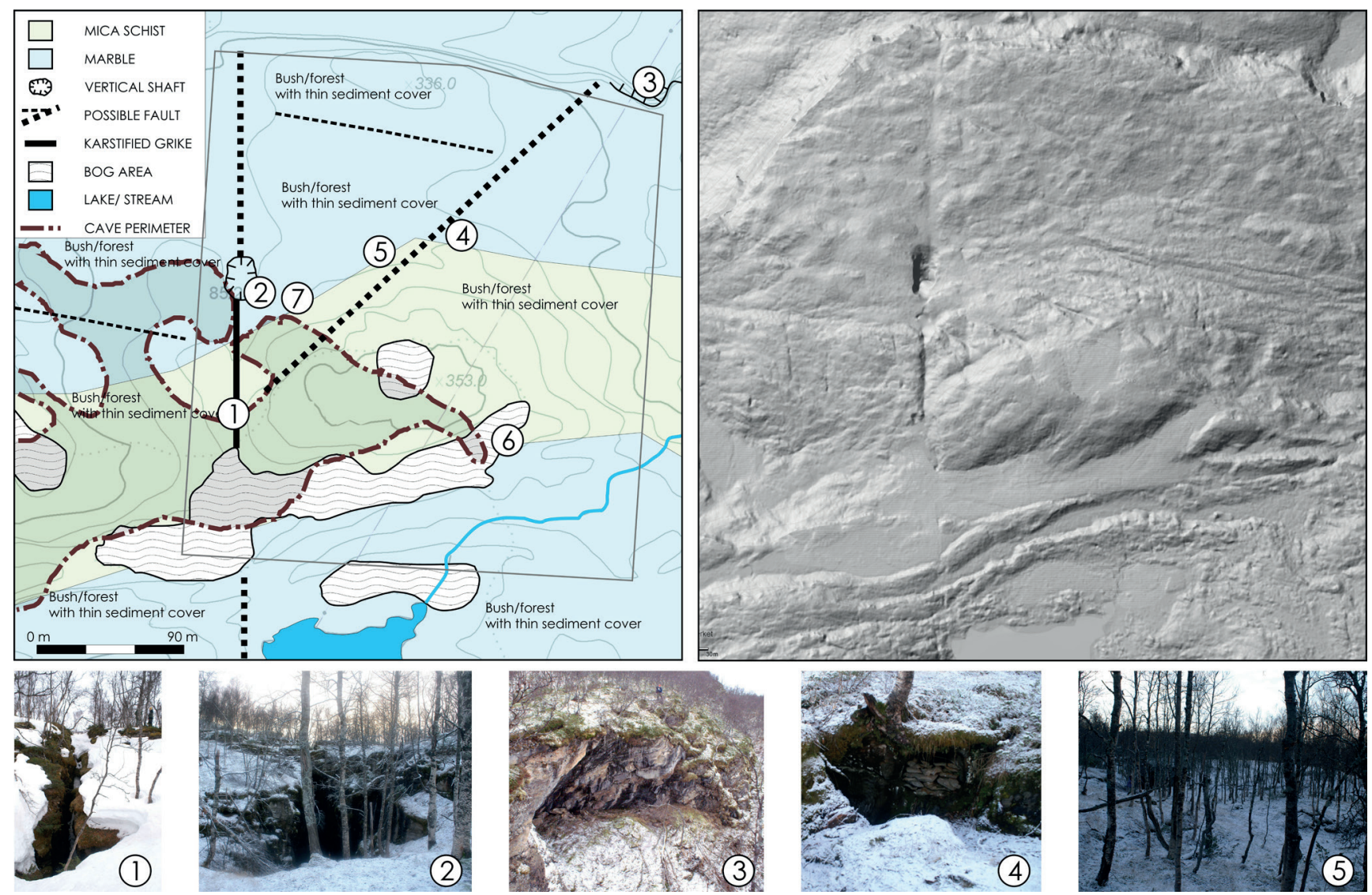

Figure 4. Upper left: Topography map with areas that may contribute to density variations affecting gravity readings, see Fig. $1 \mathrm{~A}$ for location, topographic contours (5 m spacing). North is up. Upper right: LIDAR-shaded relief map (2 points per $\mathrm{m}^{2}$ ), of same extension ( $w$ ww.hoydedata. no accessed 05.02.2018). 1 - shaft with small karst caves, 2 - collapse-filled karst pipe, 3 - rock shelter/possible cave entrance, 4 - smaller karst cave entrance, closed with old rock wall, 5 - general impression of area, 6 and 7 mark areas inside cave with indications of possible sedimentfilled passages. Oblique rectangle shows data coverage area (Figs. 7, 10 \& 11).

Dividing the major cave passages into cave room segments, the biggest single cave segment area measures approximately $90 \times 140 \mathrm{~m}$, and has a height of maximum $40 \mathrm{~m}$. The vertical distance to the surface from the cave ceiling is $50 \mathrm{~m}$ or more, see Fig. 3E. From cave surveying, smaller cave passages (up to 1-3 $\mathrm{m}$ wide and 2-4 $\mathrm{m}$ high) continue under the northwestern part of the area of interest, in addition to the main room. Therefore, smaller and hidden cave passages are expected to be found close to the surface, especially in the northern part of the area of interest (Fig. 4).

The large passages in the SHC cave display significant collapse leading to modification of the roof and walls, with an elliptical dome-like passage profile appearance (Fig. 3A, B). The cave floor is not exposed in the main cave passage parts, due to a sediment cover of unknown thickness. The sediments are from visual inspection composed of collapsed debris from roof and walls, with scattered sandy deposits of glacifluvial origin, together with dust assumed to be originating from weathering of the host rock and later distribution around the cave. The depth down to the original cave floor may therefore be tens of metres.
The cave's roof collapse moved the open cave room stratigraphically upward into the micaceous rock mass, which also contains carbonaceous zones. From the NE side of the largest cave passage segment, there are indications of a cave passage collapse with sediments clogging up the continuation of the cave passage (Fig. 4: feature 7). In the SE corner of the same NE cave passage segment, the roof comes down into a sand-filled sump, which also may point to a continuation of the cave (Fig. 4: feature 6).

The plateau within the survey area exhibits a $30 \mathrm{~m}$ height difference, with the highest point being a hill in its southern part (Fig. 4). An investigation of the plateau topography above the cave (Fig. 4) shows that there are no signs of cave passage collapse at present day. On the western side, a depression with steep sides is interpreted as a vertical cave segment filled with sediments and can thus be referred to as a collapse pipe or breccia pipe. Within the SHC, the lower end of this vertical pipe can be recognised. The vertical distance from the bottom of the depression at the land surface is calculated (using Grottolf) to be $\sim 40 \mathrm{~m}$ from the surface to the pipe shaft within the cave (Fig. 4: feature 2). Farther to the $\mathrm{NE}$, approximately $200 \mathrm{~m}$ away from the NE wall of 
the main cave passage, a rock-shelter is found with the back wall consisting of what appears to be vegetationcovered collapse sediments. This rock shelter's back wall may indicate a possible collapsed/infilled entrance to a hidden continuation of the SHC (Fig. 4: feature 3). An elongated N-S shaft in the southwestern corner of the station grid is also karst related, with smaller entrances to minor karst caves (Fig. 4: feature 1). Furthermore, small karst caves are found scattered on the plateau (Fig. 4: features 4 and 5). Karst features may also be overlain by bog areas that dominate in the southernmost part of the survey area. These extend to unknown depth, but are assumed to be no more than a few metres thick.

\section{Data and Methods}

\section{Petrophysical data}

Marble, quartzite, mica schist, amphibolite and hornblende schist are encountered in the Mefjell massif (Fig. 1B). We used density values from several outcrops within a ten $\mathrm{km}$ radius from NGU's petrophysical database (Olesen et al., 2010). Minimum, mean, median and maximum density values were calculated, and are shown in Fig. 5 and listed in Table 1. We observe varying densities within the same rock type, explained by heterogeneous lithologies and metamorphic changes. The density values are in agreement with published ranges of 2400 to $2800 \mathrm{~kg} / \mathrm{m}^{3}$ for marble, and 2550 to $3100 \mathrm{~kg} / \mathrm{m}^{3}$ for schists in general (Dentith \& Mudge, 2014).

Marble: For marble ( $\mathrm{n}=7)$, a wide range of 2610$2839 \mathrm{~kg} / \mathrm{m}^{3}$ is observed. Due to the affinity for karst dissolution, even lower density values are expected to occur. Also, inclusions are reported in marble some kilometres to the west (Roberts et al., 2001).

Schist: For the hornblende schist (sometimes conglomeratic) the densities vary from 2753 to 3031 $\mathrm{kg} / \mathrm{m}^{3}$, but the dataset is small $(\mathrm{n}=4)$. The mica schist is described as rusty, with porphyroblasts of biotite and locally hornblende. Here, 24 measurements were available, with a large range, between 2663 to $2938 \mathrm{~kg} /$ $\mathrm{m}^{3}$. The higher values may be due to porphyroblasts of heavier mineral assemblages.

Other rock types: Quartzite and amphibolite, though observed in the surroundings, are regarded as of minor occurrence and therefore not included in the modelling. Approximately $20 \mathrm{~km}$ farther west, pyroxenite is found within the same nappe.

Based on these measured densities from the surrounding outcrops, it is challenging to establish a precise background density value for the gravity modelling. Therefore, a likely scenario value with a density of $2770 \mathrm{~kg} / \mathrm{m}^{3}$ (Fig. 5) has been used, which would represent a rock composition of $75 \%$ marble and $25 \%$ mica/hornblende schist, reflecting the mean density values given in Table 1 . The density of overlying bog accumulations, mainly water-wet organic material, is set to $1000 \mathrm{~kg} / \mathrm{m}^{3}$. Cave infill is here regarded as a mixture of non-consolidated glacifluvial and rockfall sediments with high porosities and is set to $1500 \mathrm{~kg} / \mathrm{m}^{3}$.

We present simplified scenarios in terms of possible karst features and host rock in Fig. 6, matured in the modelling process.

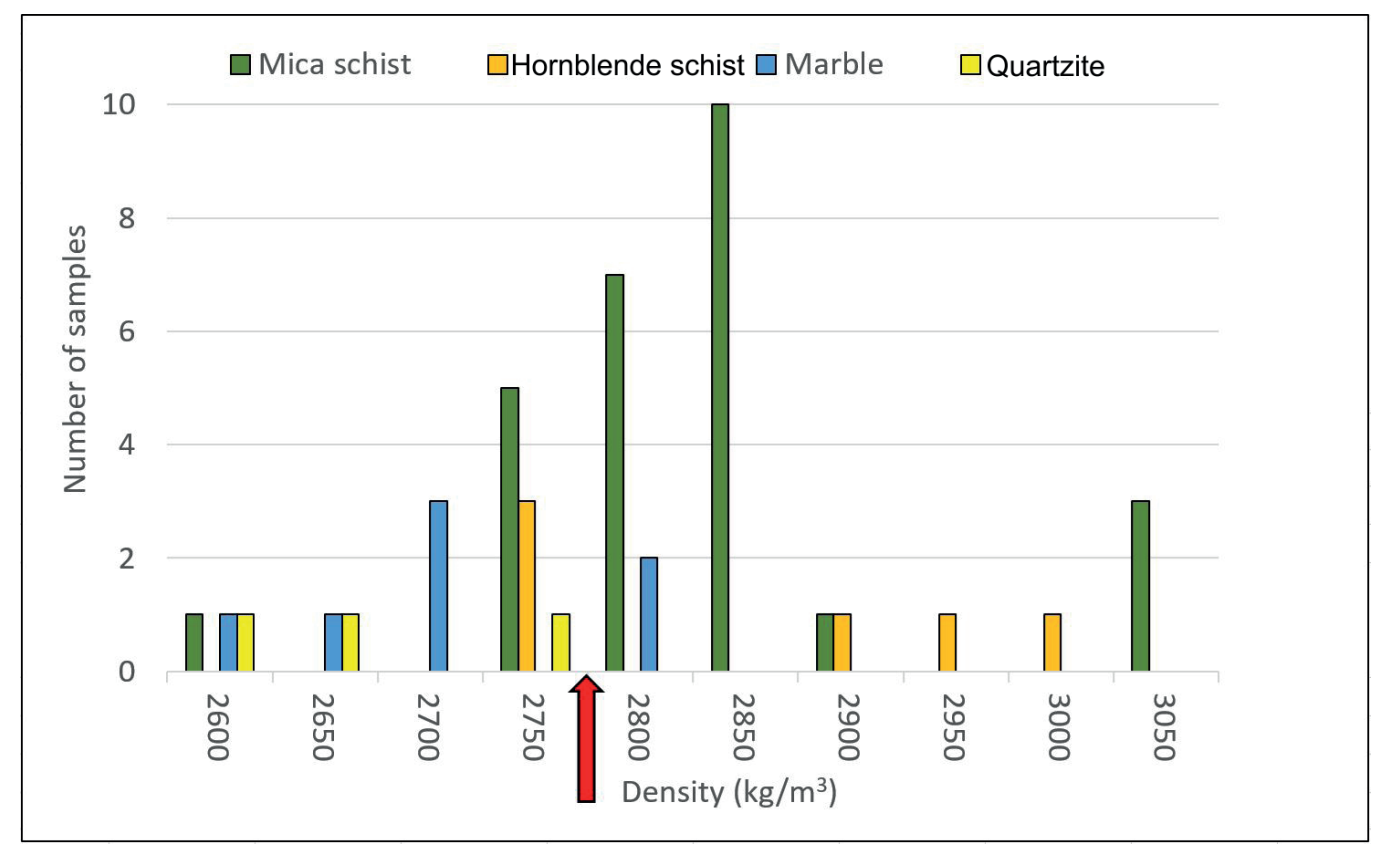

Figure 5. Distribution of density values. A density of $2770 \mathrm{~kg} / \mathrm{m}^{3}$ was chosen from a most likely scenario. 


\begin{tabular}{|c|c|}
\hline & Density $\left(\mathrm{kg} / \mathrm{m}^{3}\right)$ \\
\cline { 1 - 1 } Marble & 2770 \\
\hline Mica Schist & \\
\hline Hornblende schist & $1500-2000$ \\
\hline Karstified marble & 1000 \\
\hline Bog & 1500 \\
\hline Cave infill & 0 \\
\hline Cave (air) & \\
\hline
\end{tabular}
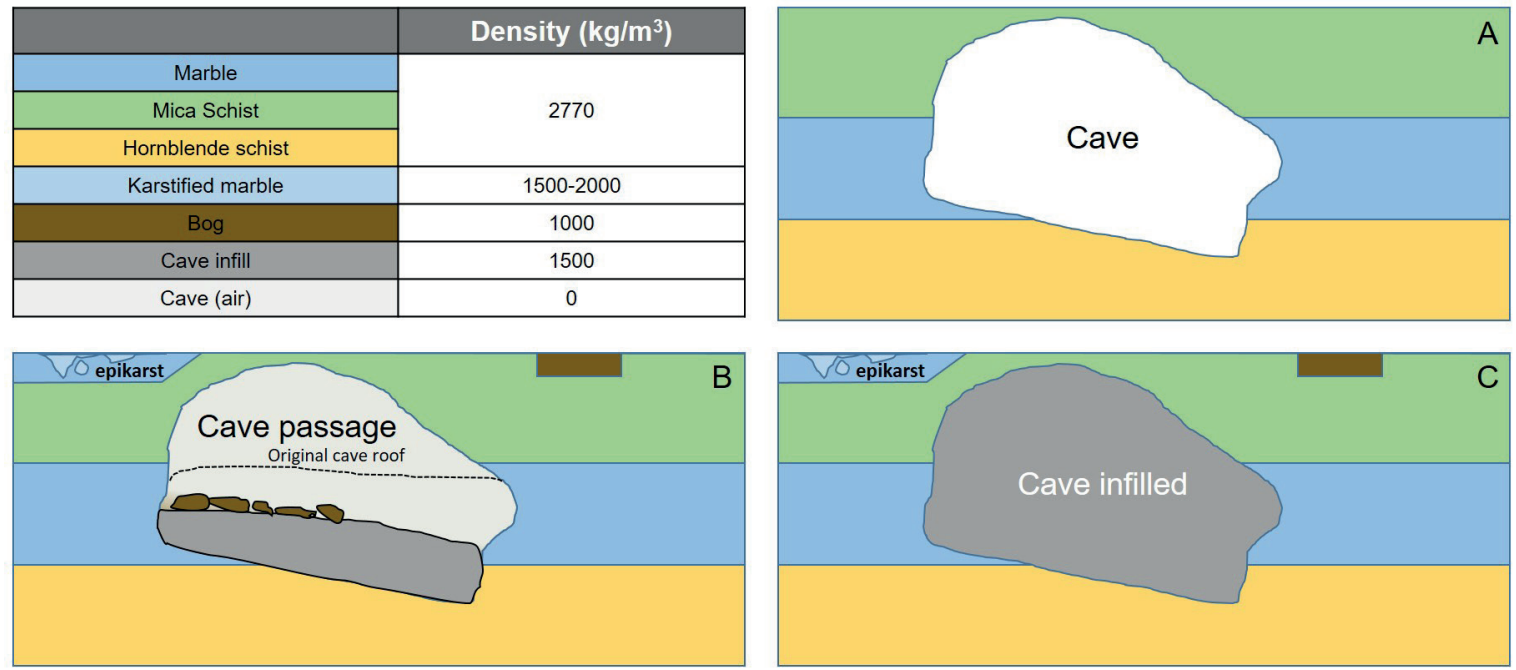

Figure 6. Concepts of karst cave in heterogeneous rock mass with (A) no infill, (B) low infill or (C) fully infilled, with rock types and densities used in the modelling.

Table 1. Statistical distribution of densities within a radius of $10 \mathrm{~km}$ from the cave area (https://www.ngu.no/emne/kartinnsyn, accessed 01.02.2018). Values are given as $\mathrm{kg} / \mathrm{m}^{3}$ and $n$ is the number of samples.

\begin{tabular}{lccccc}
\hline & Mean & Minimum & Maximum & Median & $n$ \\
\hline Mica schist & 2836 & 2663 & 2938 & 2843 & 24 \\
Hornblende schist and amphibolite & 2936 & 2753 & 3031 & 2861 & 5 \\
Marble & 2731 & 2610 & 2839 & 2719 & 7 \\
Quartzite & 2693 & 2648 & 2774 & 2656 & 3 \\
Pyroxenite & 3139 & 3037 & 3280 & 3143 & 7 \\
\hline
\end{tabular}

\section{Microgravity data}

A fieldwork campaign with gravity measurements was conducted during the late autumn of 2007 at the Mefjell massif on the northeast side of the plateau above the SHC, covering an area of approximately $280 \times 300 \mathrm{~m}$ (Figs. 4 \& 7). The station grid was designed to cover parts of the biggest cave chamber of the SHC, and an area where cave surveying and visual inspection on the land surface revealed the possibility of a cave continuation in an easterly direction.

Each gravity measurement was positioned with a Topcon differential L1-L2 GPS-GLONASS system. 95\% of the gravity stations had dGPS positions determined to better than $10 \mathrm{~mm}$ horizontal and $20 \mathrm{~mm}$ vertical. Of the remaining stations, only 4 had vertical uncertainties exceeding $200 \mathrm{~mm}$, with the worst being $511 \mathrm{~mm}$. The setup was done with a reference station with a PG-A1 antenna and a kinematic rover connected to create a local digital elevation grid model with an approximate $(20$ x 20 $\mathrm{m})$ cell size. Spike points were also established, and the cave was connected to the DGPS grid by continuing the cave survey on the outside to established DGPS points. The coordinate system used was WGS1984 UTM 33N.
Gravity data were acquired using a LaCoste\&Romberg Model D gravimeter. In order to measure the drift, each station was visited two to three times, including a base station that was visited at the beginning and end of the survey day, and several times during each day. The drift was corrected with linear trends. Free-air corrections were applied to the gravity measurement period. Ocean tides were relatively small with a maximum seawater elevation change of $1.5 \mathrm{~m}$ (www.kartverket.no/sehavniva/ tidevann-og-vannstand accessed 03.01.2017). The ocean tide gravity effect is calculated to be less than $0.1 \mathrm{mGal}$ by gravity forward modelling. The vertical displacement range by solid earth tides has been calculated using the program solid (Milbert, 2018). The vertical Earth tidal movements vary within the range of $0.07 \mathrm{~m}$ to $-0.15 \mathrm{~m}$ during the period of measurement. The gravity effect of the full range is calculated by applying the free-air gravity correction: $0.22 \mathrm{~m} \times 0.3086 \mathrm{mGal} / \mathrm{m}=0.068$ $\mathrm{mGal}$. However, both Earth and ocean tidal effects will be largely corrected by the drift correction, and are therefore not included as additional corrections.

Error estimations related to the processing steps are listed in Table 2. Altogether, we estimate an error of \pm 0.2 $\mathrm{mGal}$. Given the small area of interest, we neglect the latitude correction that would be almost constant within 


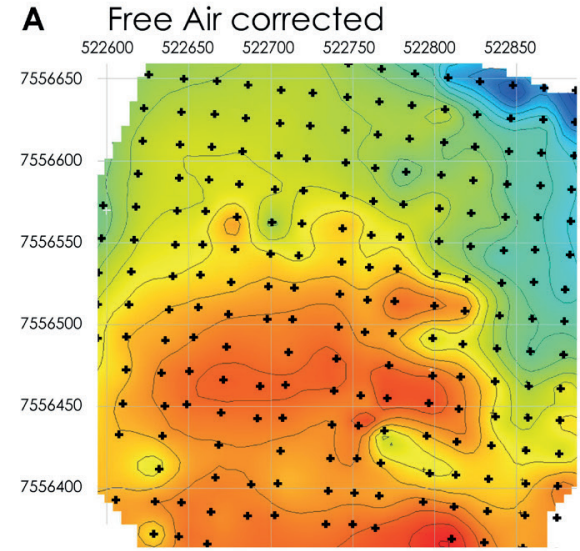

D Residual with modelling lines

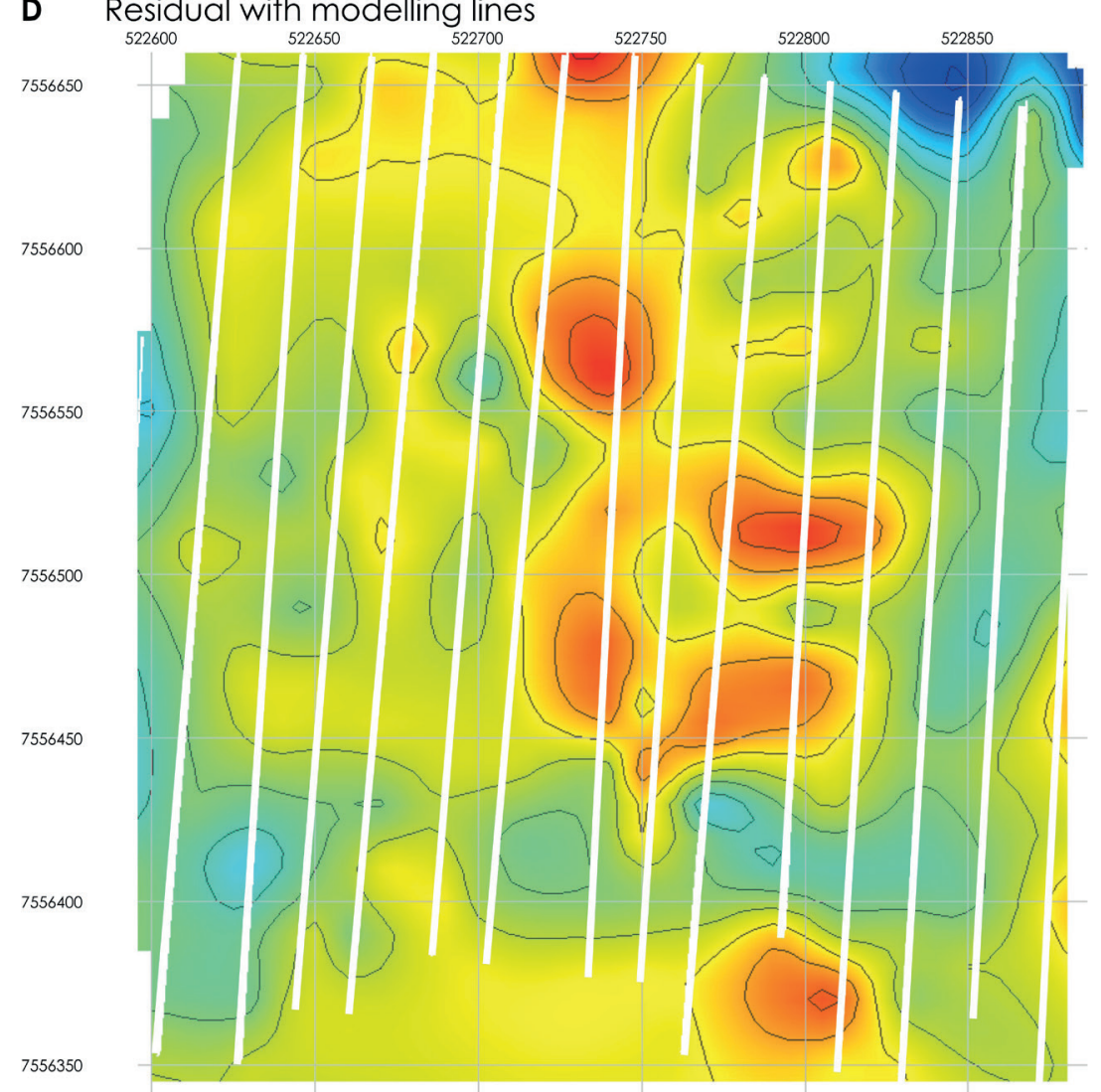

B Bouguer corrected 522800 $522600 \quad 522650 \quad 522700 \quad 522750 \quad 522800 \quad 522850$

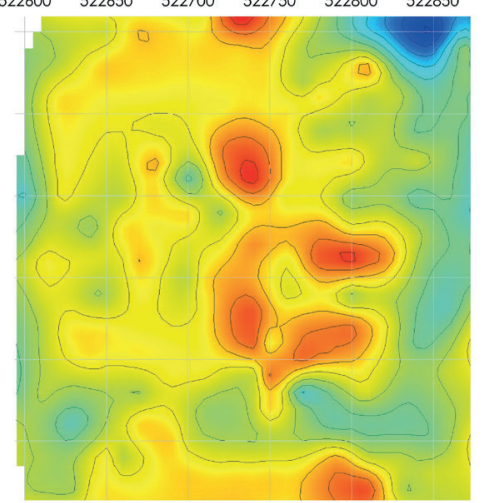

Figure 7. (A) Processed free air gravity grid and station locations (crosses), contour lines distance 0.5 mGal with gravity reading stations (black dots). (B) 3D Bouguer corrected grid. (C) Residual grid, trend corrected. (D) Trend corrected with modelling lines (white), oriented approximately $\mathrm{N}-\mathrm{S}$. (E) Regional trend.

\section{Residual (Trend corrected)} $\begin{array}{llllll}2600 & 522650 \quad 522700 & 522750 \quad 522800 & 522850\end{array}$

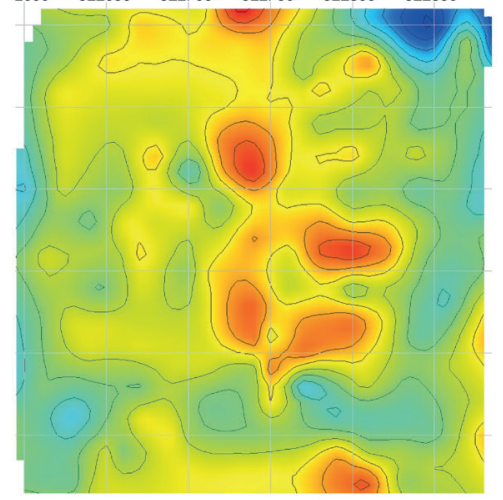

E Trend

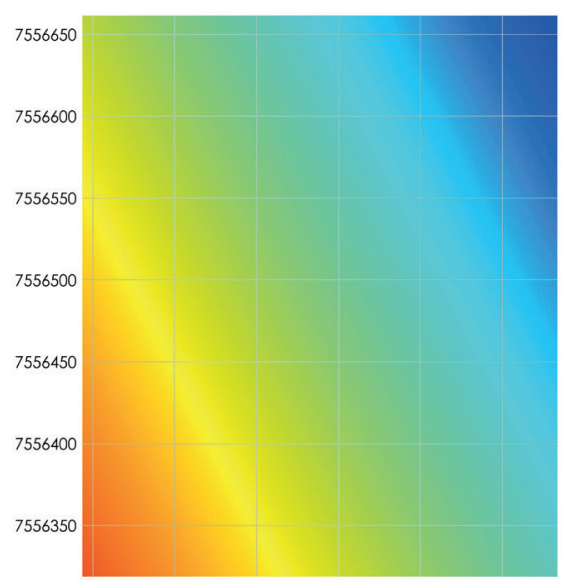

\begin{tabular}{ccccc} 
mGal & A & B & C\&D & E \\
$\square$ & 8.3 & 1.3 & 1.4 & 0.9 \\
$\square$ & 7.4 & 0.7 & 0.8 & 0.8 \\
$\square$ & 6.5 & 0.1 & 0.3 & 0.7 \\
\hline & 5.6 & -0.5 & -0.3 & 0.6 \\
$\square$ & 4.6 & -1.1 & -0.8 & 0.5 \\
$\square$ & 3.7 & -1.7 & -1.4 & 0.4 \\
$\square$ & 2.8 & -2.3 & -1.9 & 0.3 \\
$\square$ & 1.9 & -2.9 & -2.5 & 0.2 \\
$\square$ & 0.9 & -3.5 & -3.0 & 0.1 \\
\hline & 0.0 & -4.1 & -3.6 & 0
\end{tabular}

the area. All measurements are kept as relative gravity values and have not been corrected to absolute gravity values. Our approach is common for microgravimetry (Ardestani, 2008; Beres et al., 2001).

The corrected gravity values were gridded with a grid cell size of $5 \times 5 \mathrm{~m}$ and are displayed in Fig. 7, with Free air, Bouguer and residual anomalies. The same grid setup is used for the gridding of the DGPS data to make the digital elevation model.

\section{Modelling and model parameters}

Forward modelling and terrain correction were performed with software Modelvision (version 15, Tensor Research). A terrain model of the northern part of the Mefjellet mountain was constructed by converting the terrain into a body faceting the terrain surface. Facets are regular grid cells that increase in size from the centre towards the border of the area. The extent of this terrain model measures a total of $5.9 \mathrm{~km}$ in $\mathrm{E}-\mathrm{W}$ 
Table 2. Possible error sources from acquisition and processing.

\begin{tabular}{llll}
\hline Source error & Explanation & Effect mGal & Correction strategy \\
\hline Gravity readings & Reading error, instrument handling incorrect. & unknown & Repeated readings. \\
Drift correction & $\begin{array}{l}\text { Minor drift as proven by repeated base } \\
\text { measurements. }\end{array}$ & Up to several mGal. & $\begin{array}{l}\text { Applied to all points, no major drift } \\
\text { during measurement period. }\end{array}$
\end{tabular}

Free air correction

Terrain correction [3D Bouguer]

Ocean tide correction

Earth tide correction

dGPS measurements

Known cave position in rock mass
With dGPS height, generally sigma Z under $20 \mathrm{~mm} . \quad \sim 0.01 \mathrm{mGal}$

$20 * 20 \mathrm{~m}$ grid, does not acknowledge smaller terrain Up to several mGal. differences.

Modelled, less than $1.5 \mathrm{~m}$ tidal difference.

Modelled, see text.

XY: $95 \%$ of stations better than $10 \mathrm{~mm}$ horizontal

$\pm 1^{\circ}$ on compass and clinometer readings. Length by laser distance meter.

\section{$<0.1 \mathrm{mGal}$ \\ $\sim 0,05 \mathrm{mGal}$}

See Fig.1.
Applied.

Applied, details in text.

Very small, not applied.

Very small, not applied.

Extremely small, not applied.

See discussion in text. direction and $5.6 \mathrm{~km}$ in N-S direction. We used the DGPS measurements in the survey area, and a $10 \times 10$ $m$ digital elevation model (DEM) outside the study area (www.geonorge.no accessed 01.12.2017). The latter is having a vertical uncertainty of up to $2 \mathrm{~m}$. This terrain correction is a kind of a 3D Bouguer correction and was performed with the background density of $2770 \mathrm{~kg} / \mathrm{m}^{3}$ as derived from the density analysis described above. This background is used for all further modelling.

The next step was to construct a regional trend anomaly, which accounts for deeper sources in the Caledonian nappe structure. A regional gravity compilation (Fig. 8; 1 x $1 \mathrm{~km}$ grid cell size) was inspected for our wider study area. Inspection of this map shows a negative trend dipping towards the NE with an approximate $1 \mathrm{mGal} /$ $\mathrm{km}$ within our grid area. Due to the low resolution of the regional grid, this trend can only give information on the variability of the trend on a large scale. However, minor variations on the scale of the study area are possible and cannot be derived from this data. Therefore, we derive the regional trend directly from the gravity data of the study area. Regional trends are commonly defined by polynomial surfaces (cf., Martínez-Moreno et al., 2015). We chose a tilted flat surface (polynomial degree 1) with the function $\mathrm{R}=\mathrm{a}+\mathrm{bX}+\mathrm{cY}$ in order to preserve all shorter wavelengths in the study area. The parameters result in ' $a$ ' $=5832$, 'b' $=-0.00164798$ and 'c' $=-0.00083891$. The critical parameter is the offset 'a'; too small offsets will result in too high densities and vice versa. Modelling

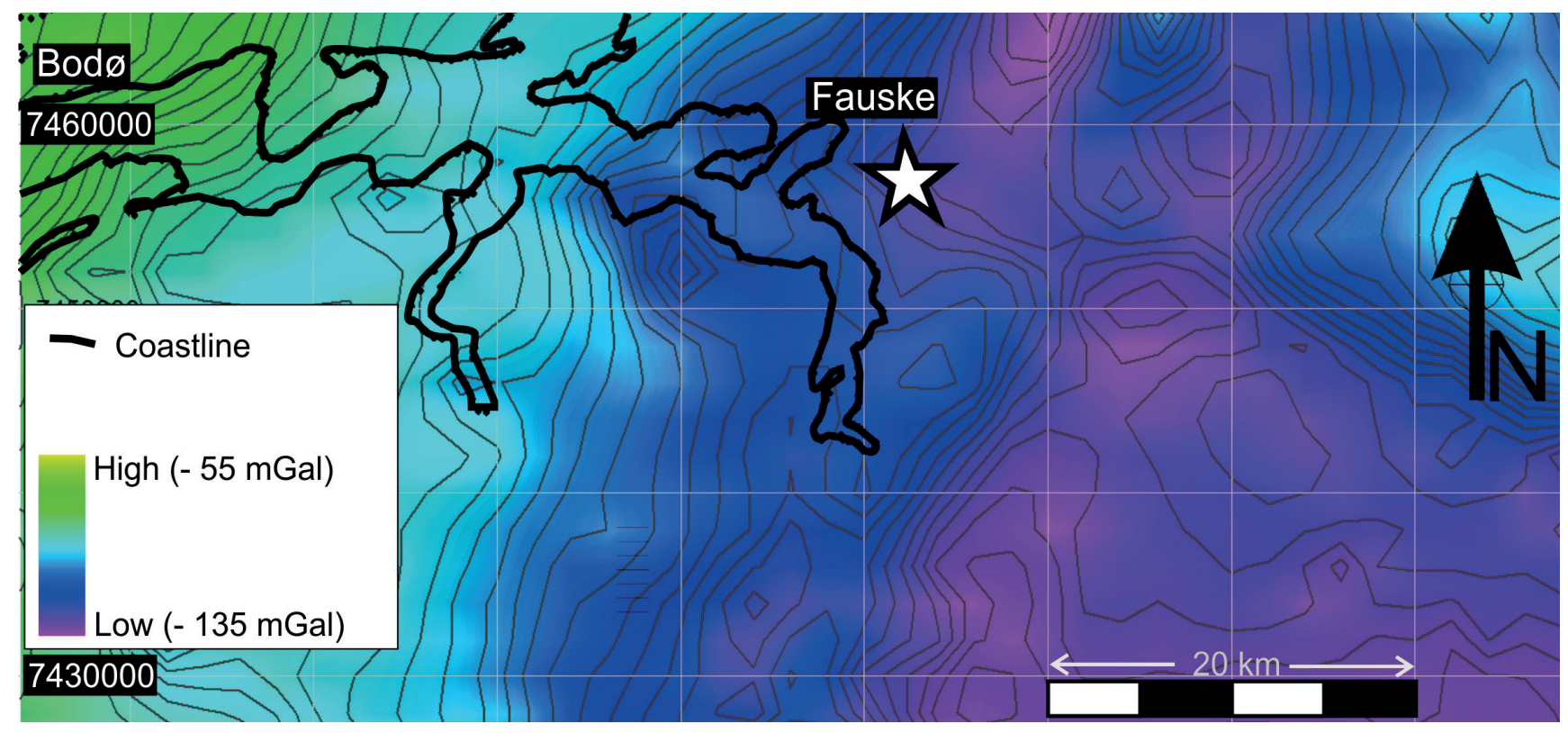

Figure 8. Bouguer gravity map of the Salten area, $1 \times 1 \mathrm{~km}$ grid cell size (Geological Survey of Norway: Gellein, 2003; Olesen et al., 2010). Note NNE-SSW-trending gravity trough with an apparent offset towards east at SHC position (star), a possible indication of regional WNW-ESEtrending fault system. 

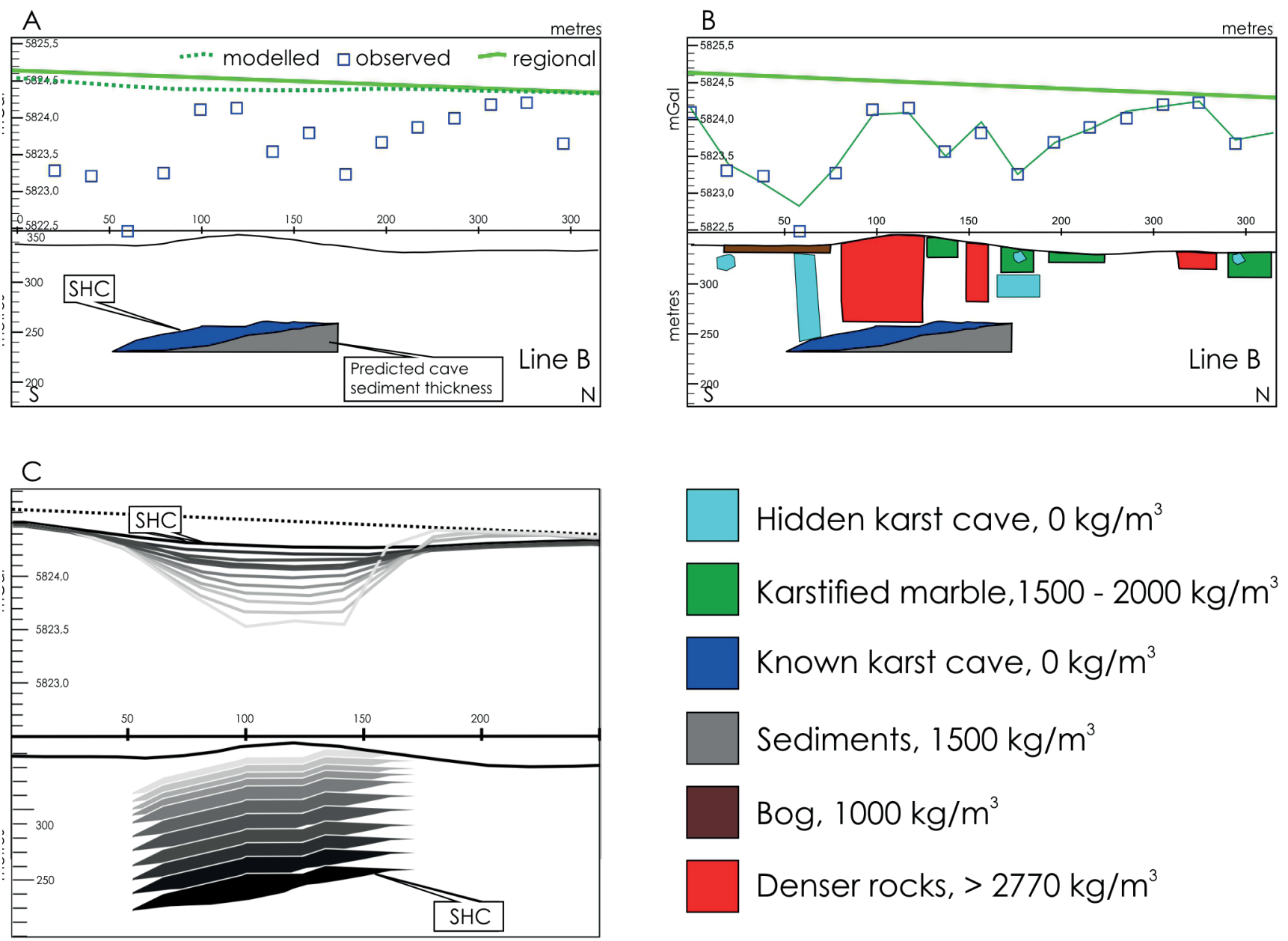

Hidden karst cave, $0 \mathrm{~kg} / \mathrm{m}^{3}$

Karstified marble, $1500-2000 \mathrm{~kg} / \mathrm{m}^{3}$

Known karst cave, $0 \mathrm{~kg} / \mathrm{m}^{3}$

Sediments, $1500 \mathrm{~kg} / \mathrm{m}^{3}$

Bog, $1000 \mathrm{~kg} / \mathrm{m}^{3}$

Denser rocks, > $2770 \mathrm{~kg} / \mathrm{m}^{3}$

Figure 9. (A) shows line B (see Fig. 12 for location) modelled with known SHC geometry and estimated sediment thickness effect at cave floor, resulting in a small anomaly. (B) shows the same line, now fully modelled to explain the observed signal. (C) Gravity anomalies of cave Svarthammarhola (SHC), modelled at known position (black) shown together with gradual uplift towards the plateau with modelling result in corresponding grey scale. For location see Fig. 13, line B.

tests varying the offset were performed and we found that the offset ' $a$ ' $=5832 \mathrm{mGal}$ resulted in the most reasonable densities. The small size of the parameters ' $b$ ' and ' $c$ ' indicates a very small tilt. The regional trend used in the modelling is shown in Fig. 7.

Modelvision software builds the geometry of the subsurface by inserting bodies of different shapes into the subsurface volume. The bodies' densities as well as the background density for the subsurface volume needs to be set by the user. All bodies within the subsurface volume contribute to the gravity anomalies. This framework defines a 3D environment with 3D bodies. Body geometries can be modified in vertical profiles or in the map plane. We use the following body types:

- Horizontal prisms, defined by its polygonal cross section in profile and/or map view, where strike angle, strike lengths and plunge can be modified.

- Frustums, with their top and bottom defined by topographic surfaces in the map plane.
The SHC cave ceiling and cave floor were exported from the Grottolf Software, imported into the Petrel software (Schlumberger) and exported to Modelvision as grid surfaces, in order to create the SHC body. An intermediate wavelength anomaly is produced by the known cave, with an anomaly strength of approximately $0.3-0.4 \mathrm{mGal}$, see Fig. 9. This calculated gravity anomaly is compared with the measured anomalies, shown in Fig. 10. The observed anomalies are smaller in wavelength and larger in anomaly size, which clearly indicates that additional shallow sources are needed (Fig. 10C).

Subsequently, further bodies were created with densities which differ from the background density in order to achieve a match between modelled and measured gravity anomalies, as well as to honour the observed geological features in a geologically realistic way (Fig. 11).

Our workflow for the data collection, processing and modelling is summarised in Fig. 12, and advantages and suggestions for improvement will be discussed below. 

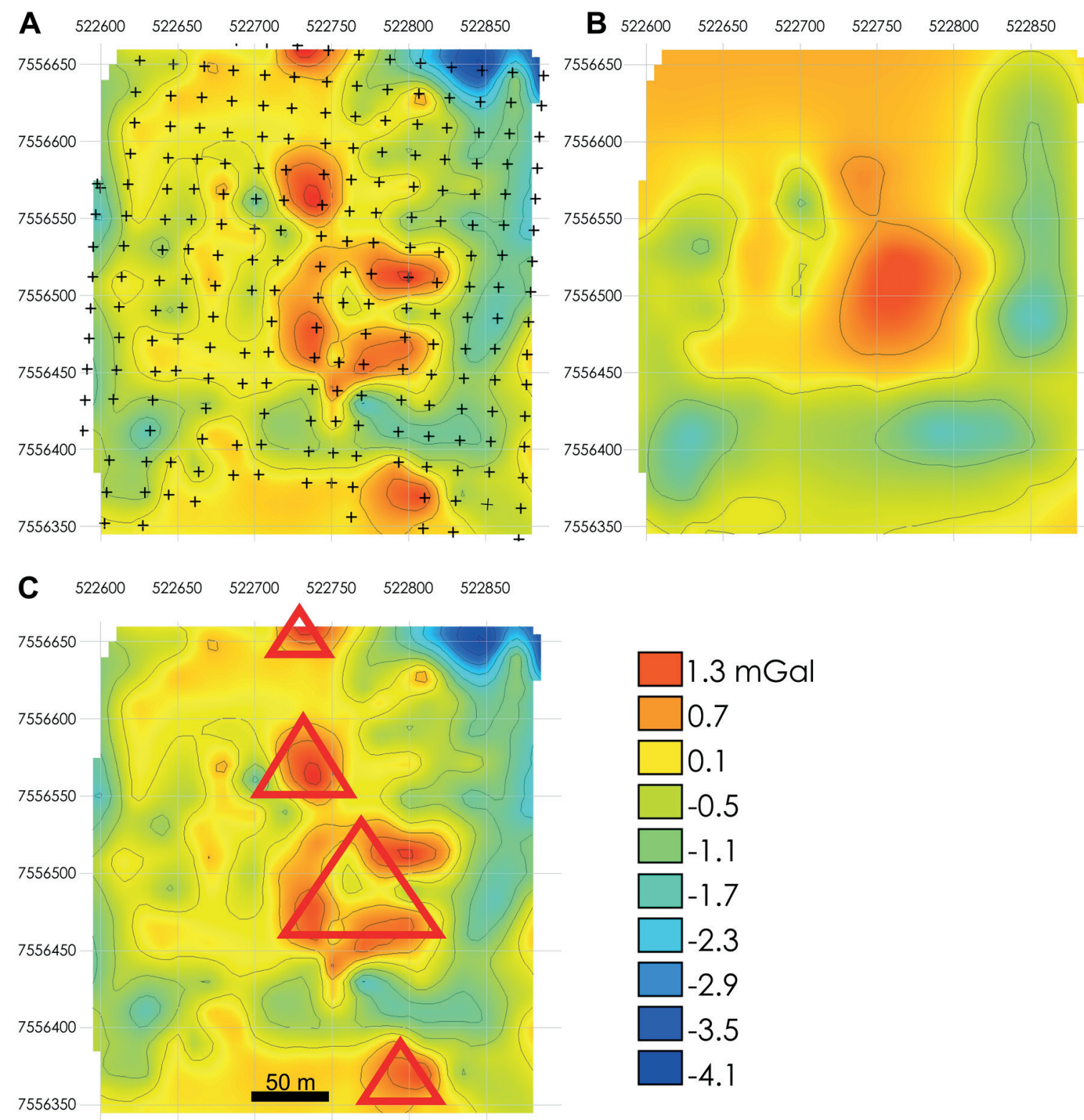

Figure 10. (A) The Bouguer corrected grid with gravity reading stations. (B) Calculated anomalies from model (residual). (C) Areas marked with red triangles indicate areas with very high densities.

\section{Modelling results}

The most plausible model result is shown as maps, sections and 3D displays in Figs. 11,13-16. Fig. 9B shows an example for a modelling profile passing both the SHC and major and minor hidden caves and karstified bedrock. The shaft at the left side of the SHC in Fig. 9B coincides with the largest negative anomaly, but no indications for this feature are found at the surface. This anomaly is defined by several points, therefore we regard the signal as trustworthy. From Fig. 11B, D, two main trends of karst occurrences can be recognised: a karstified zone above the SHC, extending towards north, and a possible prolongation of the SHC towards east, which bends after $\sim 150$ metres towards north.
Fig. 13 shows the sections with the hidden cave passages, karstified marbles, known karst caves, collapse breccia pipes, sediments and bog. Fig. 14 shows a 3D view of the entire SHC and the modelled hidden cave passages, with their altitudes highlighted by different colours.

The calculated gravity anomalies of this model are shown in Fig. 10 in comparison with the observed anomalies and show a good match for the longer wavelengths. The positive anomaly, marked by the largest red triangle in Fig. 10C (section F to J in Fig. 13), cannot be modelled within our density range for the rocks found in the area, and requires introducing higher densities as discussed below. 

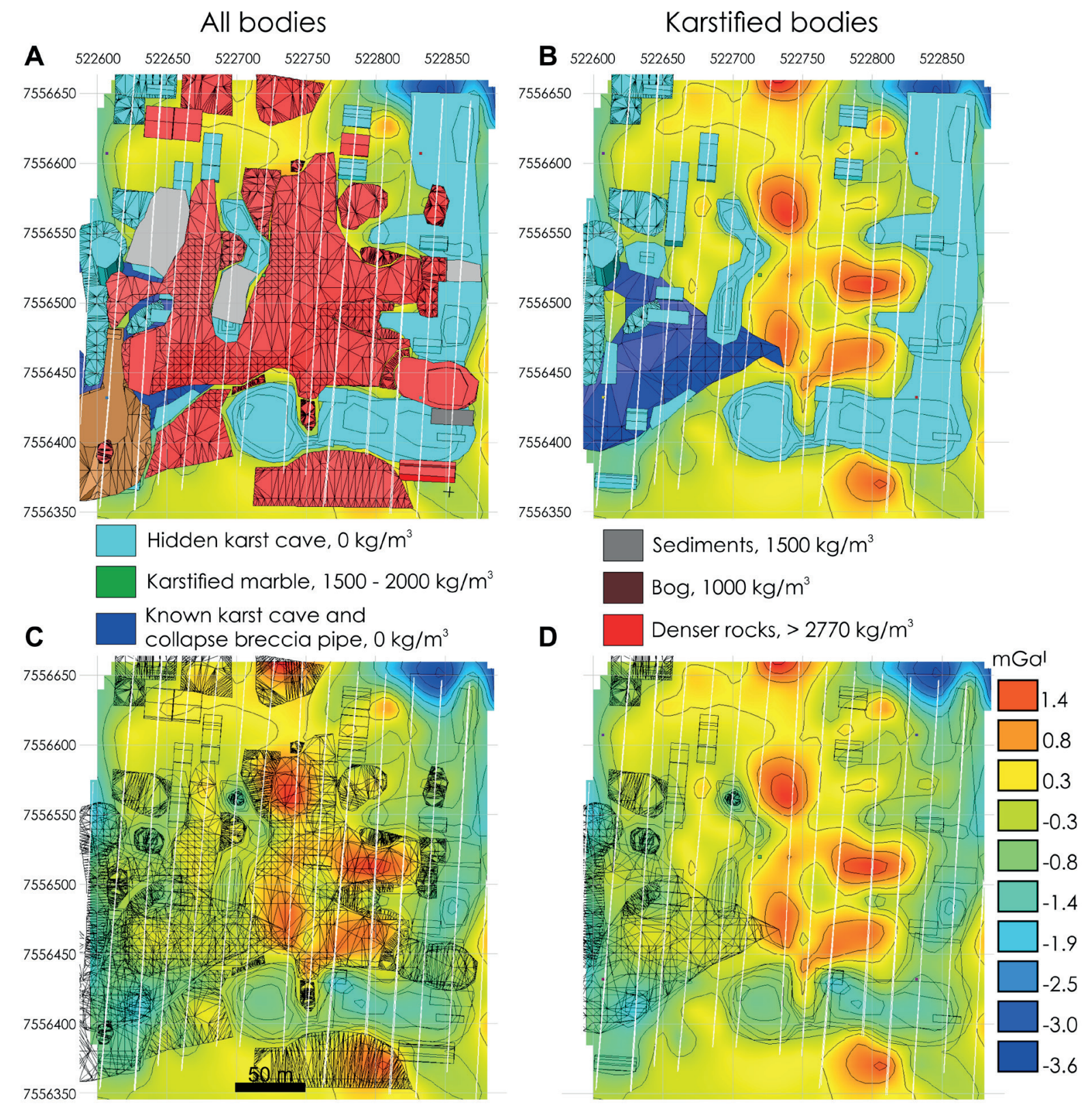

Figure 11. Overview of bodies with overlain Bouguer corrected grid, with (A) and (C) showing all bodies both filled and as wire-frame bodies. (B) and (D) show only karstified bodies filled and as wire-frame bodies.

\section{Modelled scenario uncertainties}

Due to inherent non-uniqueness of the gravimetry method, theoretically an infinite number of models could explain the observed gravity signals. However, by using geological knowledge and reasonable density values we can effectively constrain the models. We here present three different approaches for introducing uncertainties into the model, and argue for our choice of the most probable scenario that can be achieved with this type of data.

Geometry: The geometrical shapes of the deep hidden caves are strongly simplified, and are shown as boxes, as the anomalies from this depth cannot resolve complicated shapes. Uncertainty also relates to the precise depth of the cave. Moving the cave down into the rock mass, implies increasingly larger cave bodies to explain the same observed signal (Fig. 9C). We therefore investigated a 'larger cave' model scenario (Fig. 15). Although both models shown in Fig. 15 match the observed gravity signal, the 'larger cave' scenario (Fig. 15B) would most likely experience roof collapse, which would be visible from the surface, and no signs of such collapse features are seen at the plateau.

Our interpreted structures at shallow depth coincide with realistic cave passage dimensions, regarding cave stability (Lauritzen \& Mihevc, 2015).

The hidden cave passage height in this southern part is 


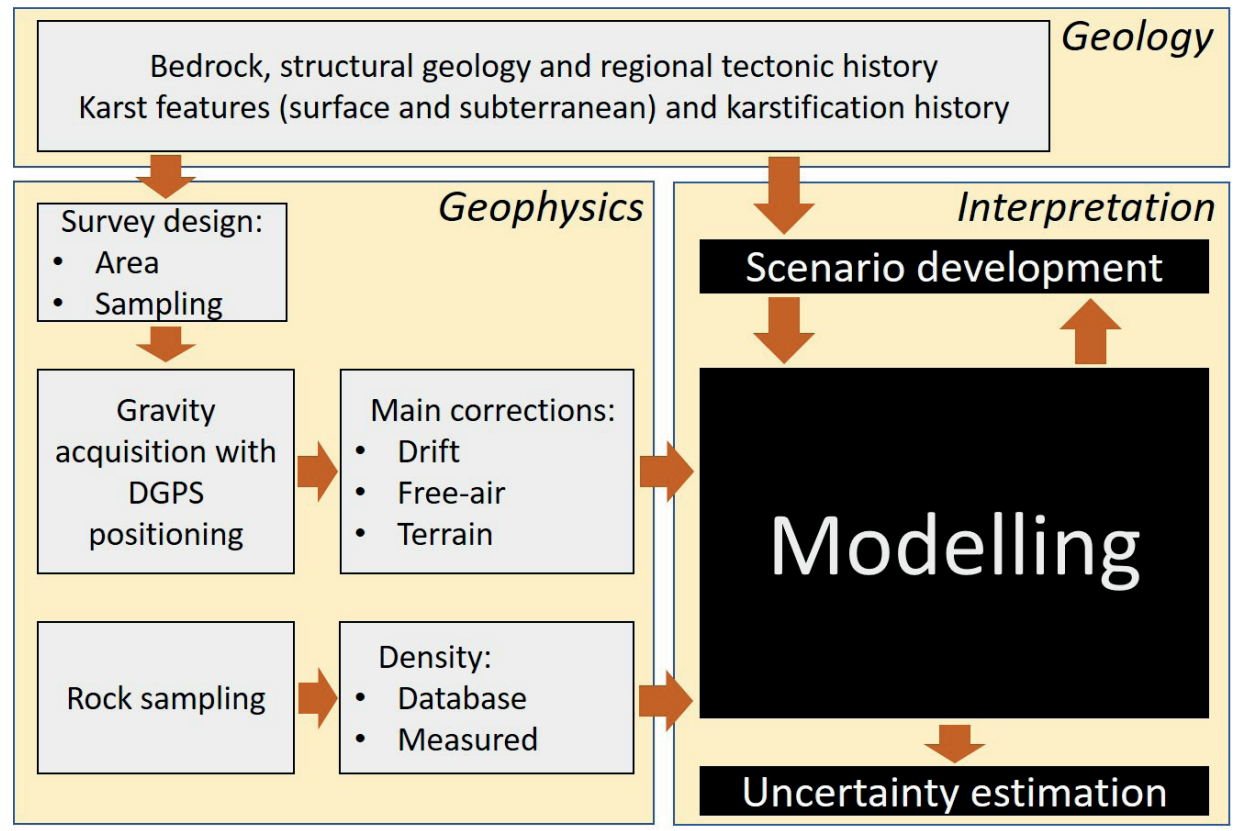

Figure 12. Proposed workflow for gravity exploration of cave passages.

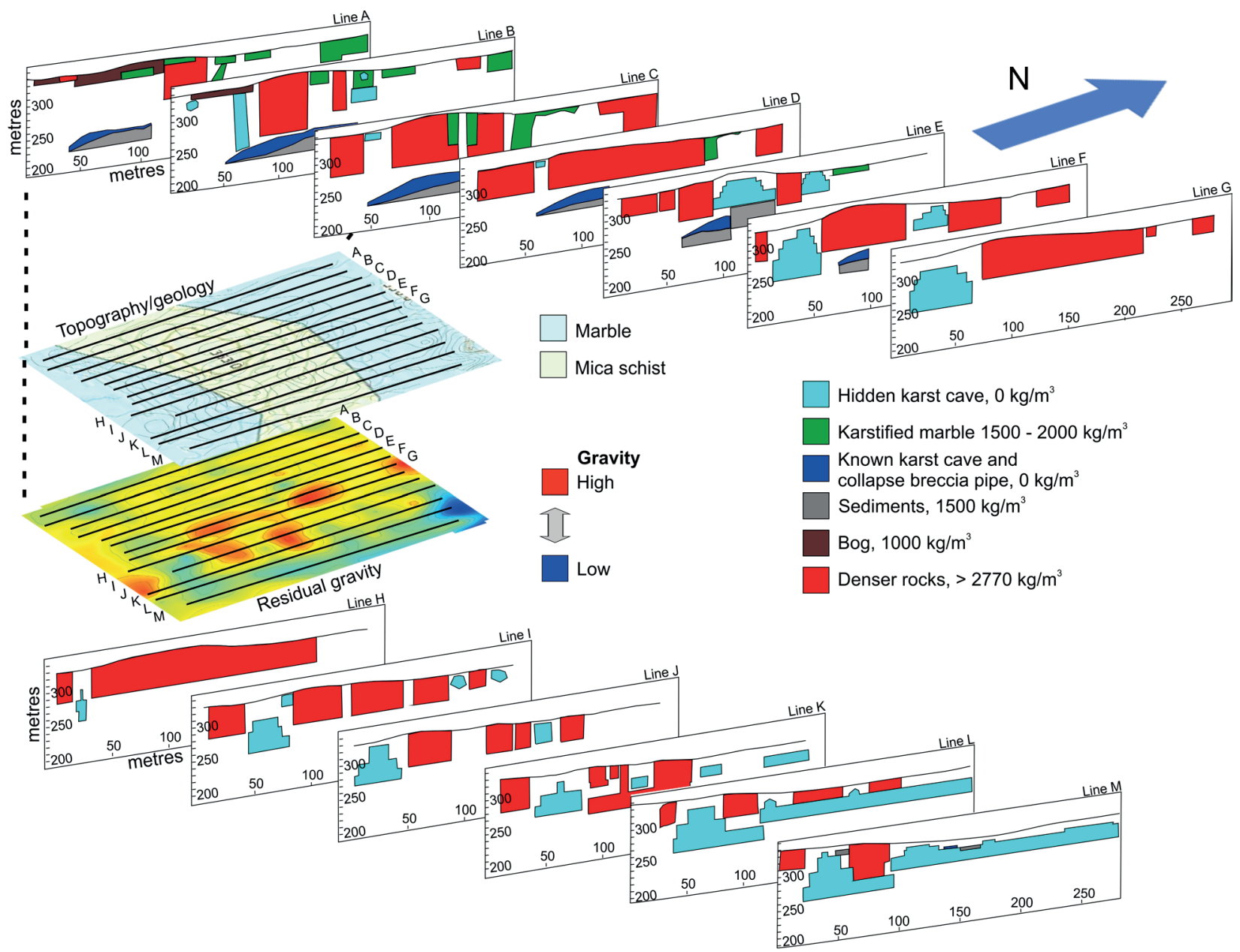

Figure 13. 3D presentation of all modelled sections, their position stated on the topography/geology map and residual gravity map. See also Figs. $11 \& 14$. 


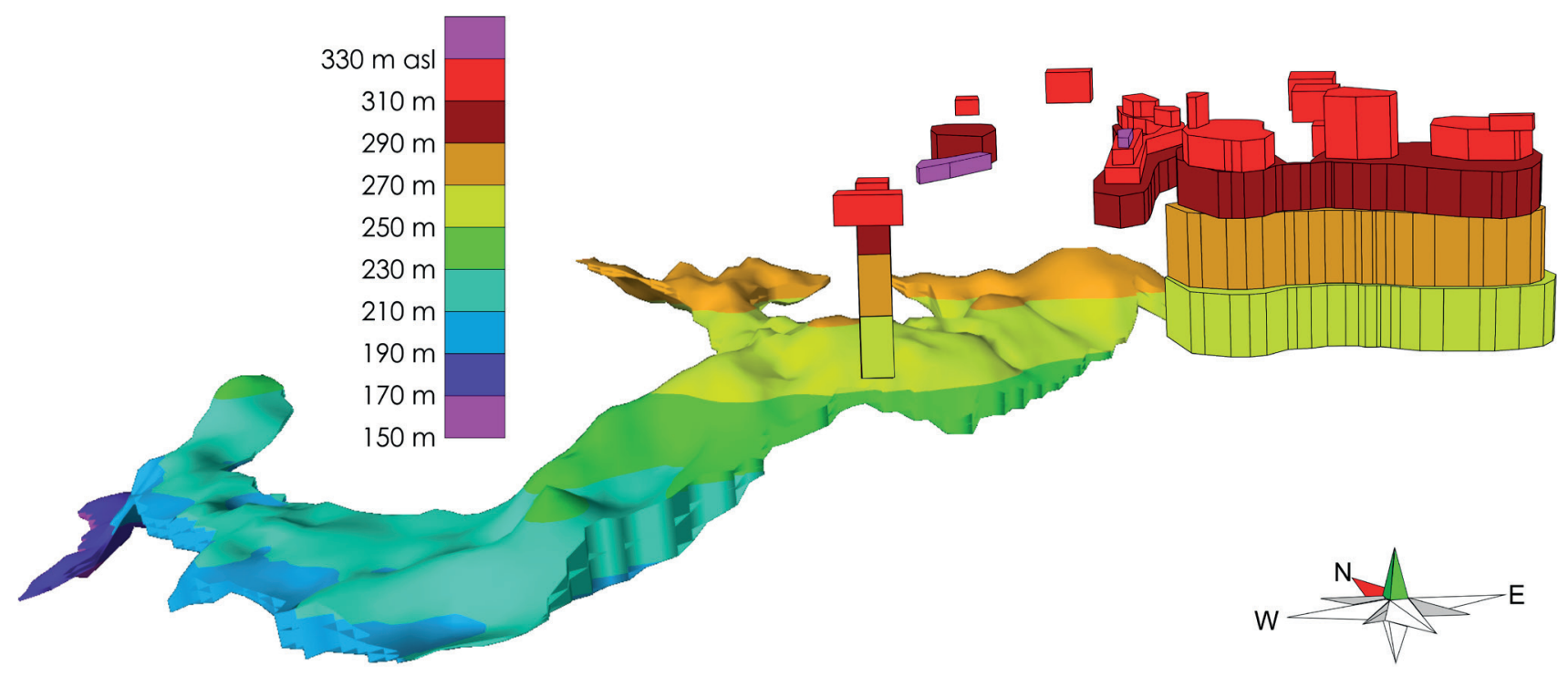

Figure 14. 3D model showing the known SHC to the left (smoothed horizons) and modelled hidden caves to the right (blocks), seen from SSW. Note large vertical height of the hidden caves.
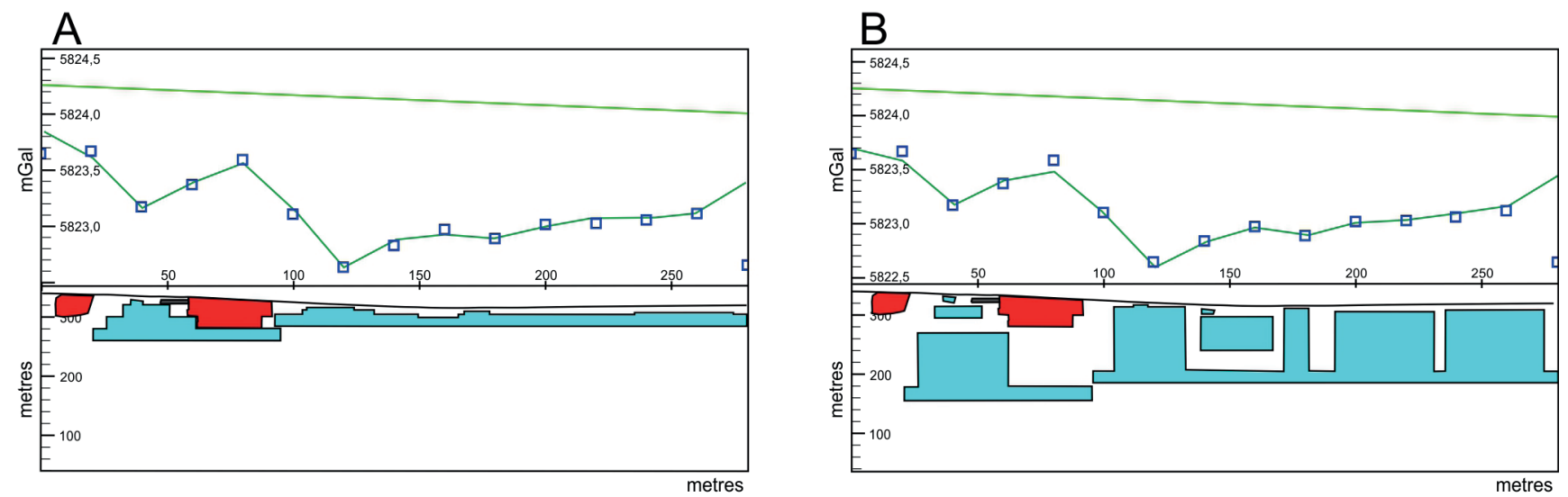

Figure 15. Modelling with two different cave ceiling depths on line M, see Fig. 13 for the position. (A) The modelled cave room with best-fit. (B) Base of cave positioned $100 \mathrm{~m}$ downwards into the rock mass.

twice the size of the SHC passage maxima. This may be explained by the cave passage being partly controlled by a steeply dipping, E-W-striking fault. The existence of this fault trend gains support from the lineament observations at the surface (Fig. 4), as well as the regional fault trend on the regional gravity map (Fig. 8). However, only a detailed in situ cave survey of the hidden cave will reveal the exact geometry of the hidden cave passages.

Cave infill: Uncertainties relate to different scenarios of the cave interior, the simplest being air-filled cave passages with a density of zero. Sediment-infilled cave passages lead to a lower gravity anomaly of the cave body. This must be compensated by a larger cave room to match the gravity response. Different sedimentological processes may give a different fabric laterally and vertically, and consequently a varying average density of the unconsolidated sediments. It is possible to encounter collapse breccia from cave roof and wall collapse, in addition to diamictons, fluvial and lacustrine sediments mainly of a glacial origin, water bodies and ice. All of these sediments are observed within the SHC today and/or on the plateau and surroundings. We therefore expect a density range of $1300-1700 \mathrm{~kg} / \mathrm{m}^{3}$; and as we do not know the composition of possible sediments in the hidden cave rooms we used an average of $1500 \mathrm{~kg} / \mathrm{m}^{3}$.

Water-filled cave passages are not observed in the upper part of the known cave, but are found in the lowermost western part outside our area of interest, near $150 \mathrm{~m}$ a.s.l.. Therefore, we do not expect standing water bodies to be encountered in the hidden cave passages, which are positioned close to the hinge line of a NNE-SSWtrending antiform (Fig. 16).

Within the SHC, a large ice body is situated in the western lower part of the cave, outside our study area. The cave ice is situated below the lowest cave entrance. The ice is 
regarded as stagnant today but shows signs of former movement, indicating that it used to be part of an active glacier. The special micrometeorological conditions within the SHC create a ventilation 'chimney effect' that freezes, preserves and cools the cave ice mass during the wintertime (Baastad, 2006). At present conditions there is a negative accumulation trend and loss of ice mass due to ablation. Therefore, we do not expect ice in the hidden cave rooms.

Host rock: A further uncertainty is linked to the choice of background density. A higher background density will lead to smaller cave rooms, but the characteristics of the geometry will be preserved. We have already discussed in the introduction that karstification does not provide just the (larger) cave void in the host rock, but also affects the host rock by creating the epikarst zone, which comprises a wider pore/permeability system than what can be seen from entering a cave (Fig. 6B, C). Furthermore, unconsolidated sediments, either by collapse or other sedimentary processes (glacial and/or glacifluvial deposition, weathering, etc.), may also reduce this epikarst density contrast. Adding 'denser' autochthonous sediments of possible siliciclastic origin may mask the epikarst porosity, together with fluids (e.g., groundwater table) filling the remaining pore space. This could both lower and increase the overall density contrast within the carbonate host rock.

Small caves may not be visible from outcrops, as they are often buried under sediment cover, but may still be
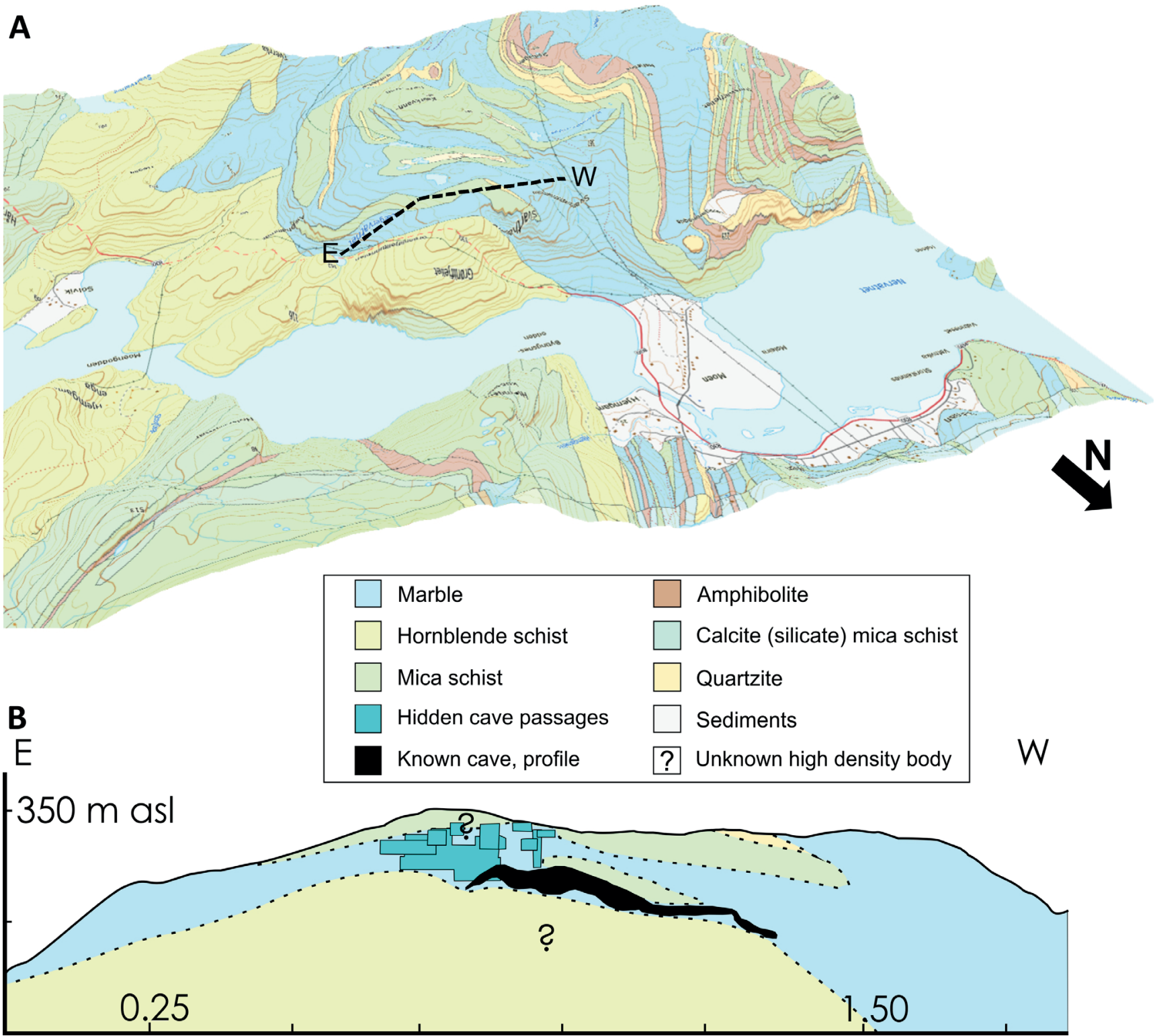

Figure 16. (A) 3D view of the Mefjell antiform, geological map (Fig. 1B) with profile indicated for (B). (B) Vertical profile through the Mefjell antiform of the simplified cave passage of SHC, and position of modelled hidden cave passages. Lithological boundaries are extrapolated from the geological map and cave inspection; for exact profile position see Fig. 1 B. 
plentiful within the rock mass. Their presence will lower the overall density of the rock.

The heterogeneous nature of the composition of the rocks in the Mefjell area, together with their folded appearance gives an additional challenge. The different observed densities in the mica schist can be attributed to impurities by both the presence of local carbonates within the mica schist (karstifiable and therefore reducing the overall density), as well as the presence of denser mineral aggregates or by local denser rock bodies of pyroxenite or amphibolites increasing the density. Furthermore, the geological map (Fig. 1B) in this folded terrane may not reveal all the rock types in the subsurface in our area of interest.

Most probable scenario: The results indicate that a larger part of the overall cave rooms must be present as an empty (non-filled) room that should be accessible by digging or drilling, as the gravity anomaly cannot be modelled using sediment infill in the hidden cave passages. Therefore, open hidden caves are most likely to be encountered.

\section{Discussion}

\section{Workflow}

Based on our modelling approach in full 3D, we here present an improved workflow (Fig. 12) for using the gravity method to detect karst in a Caledonian nappe setting. Using known geology (bedrock, structural geology and regional tectonic history) combined with local observations of karst features and ongoing interpretation of karstification history is the preferred starting point. This is the basic input for the survey design and processing including necessary corrections, together with rock density properties either from our own samples or local/regional databases. This also provides the foundation for scenario development before modelling and uncertainty estimation.

It is important for future application of the gravity method in complex structural settings to gain a rough understanding of where one can expect possible karstified rooms, at what depth and lateral extent. It is also beneficial to expand the area of interest into the non-karstified area. It is suggested to gather a few longer (regional) profiles in addition to the study grid in order to capture larger wavelengths related to deeper structures, and to gain a better understanding of the background trend of the gravity anomalies. Detailed geological mapping with rock sampling is another benefit.

This method can also be applied in other settings where gravimetry is considered an option. In a wider view, gravity exploration can be integrated with other geophysical methods that can be used to address the search for hidden cave passages, such as ground penetrating radar (e.g., McMechan et al., 2002), electrical resistivity imaging or electrical potential differences (e.g., Kaufmann et al., 2015).

\section{Continuation of the SHC and geological context}

The overall geology beneath the plateau comprises an antiform with three main lithological units (Figs. 1 \& 15). This is a simplified view and does not incorporate the heterolithic composition within the different units, nor does it acknowledge undulating lithological boundaries. While this adds uncertainties to the geometries of our model, it can be stated without doubt that open cave rooms of appreciable size exist, along with trends that can be trusted.

The modelled result also gains support from regional lineament trends (Fig. 1A). The main NE-SW foliation trend coincides with the orientation of the largest cave chamber in the SHC (outline in Fig. 4). The E-W trend of the southern part of the hidden cave matches with another known SHC trend, and is also recognised from regional lineament trends (Fig. 8). The N-S trend of the eastern part of the hidden cave is recognised in the $\mathrm{N}$-S-trending lineament in the western part of the grid (Fig. 4) which we interpret as a possible fault zone as discussed above. Fault zones are prone to karstification due to weakening of the host rock. A N-S trend is also recognised in the regional Bouguer gravity map (Fig. 8) which places the Mefjell massif into the southern part of a much larger N-S-trending gravity trough. Finally, we observe that the newly interpreted hidden caves together with the known SHC system are positioned at the top of the hinge line of a large antiform (Fig. 16).

Our model expands the present-day known SHC system (Lauritzen et al., 2005) in an eastward and northward direction. The modelled hidden caves consist of airfilled passages, matching with both suspected SHC continuations and an outside rock shelter. This is a strong indication that the modelled hidden cave systems and the SHC were previously connected. This connection is today choked by sediment infill. The largest modelled hidden caves have a similar volume and geometry as the SHC (Figs. 3 \& 15).

\section{Speleogenesis}

The characteristics of the extended SHC cave system are intriguing and are here discussed in the light of speleogenesis (initiation of the cave). In the following, we review the speleogenesis of the SHC and surrounding caves, and discuss arguments for a possible hypogene origin. The speleogenesis and evolutionary history of 
the SHC are uncertain; one speleothem from the SHC is dated, a stalagmite/flowstone plate, giving Eemian and Early Weichselian ages (Fedje, 2006). However, the speleothem was not found in situ, but is believed to have been redeposited close to its growth position within the $\mathrm{SHC}$. This date therefore provides a minimum age for the SHC given that the flowstone was originally precipitated in the cave. In Lauritzen (1990), ages for the speleogenesis of the SHC are discussed and the author concluded with the uncertain possibility of a pre-Quaternary age due to the cave's position under a possible paleic surface.

The SHC including hidden passages comprises a cave system of extraordinary size. Other cave systems with an overall similar size to the SHC have not been reported from the Nordic countries, even though some caves exhibit minor passage elements measuring similar dimensions. The SHC has previously been suggested by Lauritzen (1990) as the erosional remains of a larger cave system. Other prominent caves in the immediate neighbourhood are the Solvikhola arch and the OksholaKristihola cave system.

Solvikhola arch: A few $\mathrm{km}$ east of the SHC along the fjord valley, approximately two hundred metres altitude lower, this cave arch (Fig. 1A for location) displays a similar cave passage diameter. It has been suggested to be an erosional remnant of a larger paleo-cave system (Lauritzen, 1990).

Okshola-Kristihola cave system: North of the Mefjell massif, across the fjord valley, speleothems in this cave system (Fig. 1A) have been dated, providing ages corresponding to earlier interglacials than Eemian (Skoglund \& Lauritzen, 2010). The cave system displays a major vadose incision in its lower parts, where a more than $50 \mathrm{~m}$-high passage relief developed due to gravitational-controlled fluvial incision (Skoglund \& Lauritzen, 2010).

Combining the SHC's position at the top of the hinge of a large antiform, where we also modelled uncommonly high densities, together with the cave's outstanding size, opens for a new interpretation of the speleogenesis. The hinge of an antiform is commonly a focal point for fluids migrating from greater depths. Therefore, could the SHC system be related to hypogene (hydrothermal) karst, with a possible downward continuation of the cave passages into greater crustal depths (Klimchouk, 2014)? A hypogene origin would require upwelling groundwater circulation from the lithosphere with hydrothermal fluids and/or sulphuric gases. The antiformal setting dipping southwards into the rock mass could provide a route for deep-seated fluids migrating towards the SHC. As earlier discussed, high-density bodies are required due to the constraints of the known structure and lithology (Figs. 10C \& 11A), which could also be explained by a paleokarst setting with cave passages infilled by ore deposits, or the cave room is infilled with lithified sediments or diverse precipitates. Another possible explanation could be that within the carbonates we may find Mississippian Valley Type ore deposits, as known from United Kingdom, USA and elsewhere (Leach et al., 2010).

In a hydrothermal system one may also expect deposition of gypsum/anhydrite in substantial amounts, but these are not known from the SHC. However, the preservation of evaporites is doubtful as late glacial flushing episodes of melting water would probably dissolve or erode such deposits, with collapse material filling in any passage extension continuing deeper down into the crust.

A related question is where would other cave passages from the same deeper hypogene system reach the present-day surface? Solvikhola may be a candidate to be part of such an extensive system, whereas the larger cave passages of the Okshola-Kristihola cave system have been explained as a product of meteoric karst alone (Skoglund \& Lauritzen, 2010).

With our present knowledge we cannot distinguish between a meteoric and a hypogean origin for the SHC. The hypogene hypothesis can only be tested by invasive sampling in the known and hidden cave system, combined with further geophysical exploration.

\section{Offshore analogues}

In hydrocarbon and groundwater exploration studies, karstified rocks are loosely described as rocks with secondary porosity on a wide range of scales. Such rocks can form important reservoir rocks for groundwater or hydrocarbons. Recent hydrocarbon discoveries in carbonate rocks from exploration wells in the Norwegian sector of the Barents Sea are the wells 7120/1-3 'Gohta', 7220/11-1 'Alta' and 7220/6-2 'Neiden' (www.npd.no accessed 03.01.2018). In those exploration settings, karstic properties may be challenging for drilling and production. Conductive pathways due to caves and other karst features potentially create zones of extreme permeability, which along with the occurrence of highly heterogeneous rock properties may affect the sealing and lead to the establishment of leakage routes through the reservoir overburden.

Our near-surface observations also have implications for detecting and interpreting large karstic cave systems in offshore settings at much deeper depths, an example being the karstified reservoir at $2 \mathrm{~km}$ depth below the sea surface in the 7220/11-1 'Alta' discovery offshore northern Norway. As discussed in the introduction (Fig. 2), gravity anomalies decay with increasing depths and also lose short-wavelength information. Therefore, gravimetry is not the preferred method for detecting large cave systems at such depths, but could potentially detect karstified rock volumes due to the established fact that the overall density 
of the host carbonate body is lowered. For the SHC case, the low density anomaly is not only attributed to larger caves but also the epikarst zone. This epikarst zone may be thicker than $10 \mathrm{~m}$ in a near-marine setting and also be laterally very extensive, as fluctuating sea levels over time would give further dissolution together with widening and expansion of cave systems (Mylroie \& Mylroie, 2007). This modelling study may therefore provide a useful analogue for quantifying the expected gravity anomalies in deeper karst systems.

\section{Environment}

Caves, due to their low energy environment, can also be important sedimentary archives for the natural history of the surrounding area and for the geological history of the cave itself. They are thus vulnerable for destruction by human entry (Lauritzen, 1991; Ford \& Williams, 2007). In our area, we have an incomplete sedimentary record since glacial erosion has removed and/or redistributed sediments and rocks on the surface (e.g., Andersen, 1975; Mangerud, 2004). The implications of this, if further investigations confirm our interpretation of a hidden cave, are important and not without complications. The possibility of encountering sediments and speleothems of a Neogene age or older, susceptible for dating, is intriguing and should be a focus for further work. The hidden continuation of the SHC may contain important and unknown clues, from sediment infill and other speleothems, for the natural history of the area. Due to the vulnerable underground environment and the value of potential natural history data; e.g., zoological, glacial, and vegetational history to be extracted from the cave, a careful and planned investigation must take place to make sure that all possible information is retrieved in a sound, scientific way.

\section{Summary}

1. We have demonstrated how gravity field - surveying and modelling - is a useful tool for the detection of hidden cave passages in complex orogenic nappe settings. The results of this shallow subsurface exploration of karst features in the gravity data give useful constraints for the potential use for gravity field data also in mapping more deeply buried karstified terrain.

2. We present a workflow for gravity investigation where there is potential for detection of hidden cave passages.

3. Observed gravity lows have been interpreted as hitherto unknown and inaccessible cave rooms, some of which correspond with collapse features seen in the Svarthammarhola (SHC), and from a rock shelter at the surface. This expands the known cave system in an eastward and northward direction.

4. Interpretation challenges are related to density variations caused by heterogeneous lithology of the host rock, zones of karstification (epikarst, smaller karst caves, etc.), and sediment infill leading to lower density contrasts. These challenges have been addressed by testing different density values for different scenarios, based on observations in the SHC.

5. Some gravity highs indicated the presence of highdensity rocks, where amphibolites, pyroxenites or hydrothermally altered carbonates are regarded as quite probable.

6. Combining the cave's position at the top of the hinge of a large antiform, where we also modelled uncommonly high densities, together with the cave's outstanding size, opens for new interpretations of the speleogenesis. We infer a hypogene karst origin. This issue should be addressed in further work, including geochemical investigations and by applying other geophysical methods.

Acknowledgements. The present study was conceived by Stein-Erik Lauritzen, (SEL) under the Svarthammar Research Project (Norwegian Research Council, Norpast2; Lauritzen et al., 2005) and initial fieldwork funded through the Department of Earth Sciences, UiB ('såkornmidler') to him and Arne Gidskehaug. The task was later merged into a $\mathrm{PhD}$ project for Terje Solbakk (TS), supervised by SEL and Walter Wheeler (WW) at the University of Bergen and Center of Integrated Petroleum Research. WW and TS thank The Norwegian Research Council for field expenses and salary support (NFR 176132, Paleokarst Reservoirs: An integrated 3D approach to heterogeneity, reservoir- and seismic modelling). NGU is thanked for loan of DGPS equipment and kind permission to use gravity data. The presented study is finalised as a part of TS' PhD project under the ARCEx project (Research Centre for Arctic Petroleum Exploration) which is funded by the Research Council of Norway (grant number 228107) together with 10 academic and 9 industry partners. We thank Arne Gidskehaug, Kjetil Broberg, Bjørn Solbakk, Tor Inge Korneliussen, Sylvia (Vangen) Slåttkjær and Hans-Martin Slåttkjær for their assistance during the fieldwork, and Terje Larsen and his family for their hospitality. The authors also wish to thank Marco Brönner and Odleiv Olesen for helpful discussions. We want to express our sincere thanks to Zuzana Alasonati Tašárová and an anonymous reviewer for improving our manuscript.

\section{References}

Agyei-Dwarko, N.Y., Augland, L.E. \& Andresen, A. 2012: The Heggmovatn supracrustals, North Norway-A late Mesoproterozoic to early Neoproterozoic (1050-930Ma) terrane of Laurentian origin in the Scandinavian Caledonides. Precambrian Research 212, 245-262. https://doi.org/10.1016/j.precamres.2012.06.008.

Andersen, B.G. 1975: Glacial geology of northern Nordland, North Norway. Universitetsforlaget, Trondheim, 74 pp.

Andreassen, K.A. 1969: Bergtatt. In newspaper: Nordlands Framtid, Bodø. Date 11.10.1969. 
Ardestani, V.E. 2008: Modelling the karst zones in a dam site through micro-gravity data*. Exploration Geophysics 39, 204-209. https://doi.org/10.1071/EG08022.

Baastad, L. 2006: Ventilasjonseffekter og mikroklima i Svarthammarhola i Fauske. MSc thesis, University of Bergen, 82 pp.

Barrows, L. \& Fett, J.D. 1985: A high囚precision gravity survey in the Delaware Basin of southeastern New Mexico. Geophysics 50, 825833. https://doi.org/10.1190/1.1441957.

Beres, M., Luetscher, M. \& Olivier, R. 2001: Integration of groundpenetrating radar and microgravimetric methods to map shallow caves. Journal of Applied Geophysics 46, 249-262. https://doi.org/10.1016/S0926-9851(01)00042-8.

Braitenberg, C., Sampietro, D., Pivetta, T., Zuliani, D., Barbagallo, A., Fabris, P., Rossi, L., Fabbri, J. \& Mansi, A.H. 2016: Gravity for Detecting Caves: Airborne and Terrestrial Simulations Based on a Comprehensive Karstic Cave Benchmark. Pure and Applied Geophysics 173, 12431264. https://doi.org/10.1007/s00024-015-1182-y.

Butler, D.K. 1984: Microgravimetric and gravity gradient techniques for detection of subsurface cavities. Geophysics 49, 1084-1096. https://doi.org/10.1190/1.1441723.

Chico, R.J. 1964: Detection of caves by gravimetry. International Journal of Speleology 1, 101-108. https://doi.org/10.5038/1827-806X.1.1.11.

Dentith, M. \& Mudge, S.T. 2014: Geophysics for the Mineral Exploration Geoscientist. Cambridge University Press, 9780521809511. https://doi.org/10.1017/CBO9781139024358.

Drivenes, K., Sørensen, B.E. \& Larsen, R.B. 2016: Orogenic degassing, scapolitization and K-metasomatism during Caledonian exhumation, Helgeland, Norway. Norwegian Journal of Geology 96, 223-244. https://doi.org/10.17850/njg96-3-04.

Fedje, E. 2006: A paleoclimate proxy record for the Fauske area based on the stable isotope record preserved in speleothem and dated by the TIMS method. MSc thesis, University of Bergen, $168 \mathrm{pp}$.

Ford, D. \& Williams, P.D. 2007: Karst hydrogeology and geomorphology. John Wiley \& Sons, 978-0-470-84996-5, 576 pp. https://doi.org/10.1002/9781118684986.

Gellein, J. 2003: Gravimetrisk residualkart, Sulitjelma, scale 1:250,000, Norges geologiske undersøkelse.

Heap, D. 1970: Report of the Speleological Expedition to Arctic Norway. William Hulme's Grammar School. 21 pp.

Kaufmann, G. \& Romanov, D. 2009: Geophysical investigation of a sinkhole in the northern Harz foreland (North Germany). Environmental Geology 58, 401-405. https://doi.org/10.1007/s00254-008-1598-0.

Kaufmann, G., Nielbock, R. \& Romanov, D. 2015: The Unicorn Cave, Southern Harz Mountains, Germany: From known passages to unknown extensions with the help of geophysical surveys. Journal of Applied Geophysics 123, 123-140. https://doi.org/10.1016/j.jappgeo.2015.10.004.

Klimchouk, A. 2014: The Methodological Strength of the Hydrogeological Approach to Distinguishing Hypogene Speleogenesis. In Klimchouk, A., Sasowsky, I.D., Mylroie, J., Engel, S.A. \& Engel, A.S. (eds.): Hypogene Cave Morphologies, Selected papers and abstracts of the symposium held February 2 through 7, 2014, San Salvador Island, Bahamas, Karst Waters Institute Special Publication 18, Karst Waters Institute, Leesburg, Virginia, pp. 4-12. https://doi.org/10.13140/2.1.1187.3287.

Kollung, S. \& Gustavson, M. 1995: Rognan. Berggrunnskart; Rognan; 21293, scale 1:50,000, Norges geologiske undersøkelse.

Lauritzen, S.-E. 1990: Tertiary caves in Norway; a matter of relief and size. Cave Science 17, 31-37.

Lauritzen, S.-E. 1991: Karst resources and their conservation in Norway. Norsk Geografisk Tidsskrift - Norwegian Journal of Geography 45, 119-142. https://doi.org/10.1080/00291959108552266.

Lauritzen, S.-E. 2008: Grottolf 4.027, Program for Processing, plotting and analysis of cave survey data.

Lauritzen, S.-E. 2010: Grotter - Norges ukjente underverden. Tun Forlag, Oslo, $240 \mathrm{pp}$.
Lauritzen, S.-E. \& Mihevc, A. 2015: Large-passage cross-sections : the A-frame lesson. In: Zupan Hajna, N., Mihevc, A. \& Gostincar, P. (eds.). Caves - exploration and studies : program \& excursions \& UIS \& abstracts. 23rd International Karstological School "Classical Karst", Postojna, Slovenia: Karst Research Institute ZRC SAZU.

Lauritzen, S.-E., Baastad, L., Bjørlien, J., Fedje, E. \& Holmlund, P. 2005: The Svarthamar cave research project, Fauske, north Norway. 14th International Congress of Speleology, 21-28 August, Athen-Kalamos, $5 \mathrm{pp}$.

Leach, D.L., Bradley, D.C., Huston, D., Pisarevsky, S.A., Taylor, R.D. \& Gardoll, S.J. 2010: Sediment-hosted lead-zinc deposits in earth history. Economic Geology 105, 593-625. https://doi.org/10.2113/gsecongeo.105.3.593.

Lidmar-Bergstrom, K., Naslund, J.O., Ebert, K., Neubeck, T. \& Bonow, J.M. 2007: Cenozoic landscape development on the passive margin of northern Scandinavia. Norwegian Journal of Geology 87, 181-196.

Mangerud, J. 2004: Ice sheet limits in Norway and on the Norwegian continental shelf. In Ehlers, J. \& Gibbard, P. (eds.): Quaternary Glaciations - Extent and Chronology 2, Elsevier, Amsterdam, pp. 271-294. https://doi.org/10.1016/S1571-0866(04)80078-2.

Martínez-Moreno, F.J., Galindo-Zaldívar, J., Pedrera, A., Teixido, T., Ruano, P., Peña, J.A., González-Castillo, L., Ruiz-Constán, A., LópezChicano, M. \& Martín-Rosales, W. 2014: Integrated geophysical methods for studying the karst system of Gruta de las Maravillas (Aracena, Southwest Spain). Journal of Applied Geophysics 107, 149-162. https://doi.org/10.1016/j.jappgeo.2014.05.021.

Martínez-Moreno, F.J., Galindo-Zaldívar, J., Pedrera, A., Teixidó, T., Peña, J.A. \& González-Castillo, L. 2015: Regional and residual anomaly separation in microgravity maps for cave detection: The case study of Gruta de las Maravillas (SW Spain). Journal of Applied Geophysics 114,1-11.https://doi.org/10.1016/j.jappgeo.2015.01.001.

McMechan, G.A., Loucks, R.G., Mescher, P. \& Zeng, X. 2002: Characterization of a coalesced, collapsed paleocave reservoir analog using GPR and well-core data. Geophysics 67, 1148-1158. https://doi.org/10.1190/1.1500376.

Milbert, D. 2018: http:/geodesyworld.github.io/SOFTS/solid.htm; based on an edited version of the dehanttideinelMJD.f source code by Professor V. Dehant. This code is an implementation of the solid earth tide computation found in section 7.1.2 of the IERS Conventions (2003), IERS Technical Note No. 32. Accessed: 24.05.2018.

Mylroie, J.R. \& Mylroie, J.E. 2007: Development of the carbonate island karst model. Journal Of Cave And Karst Studies 69, 59-75.

Olesen, O., Brönner, M., Ebbing, J., Gellein, J., Gernigon, L., Koziel, J., Lauritsen, T., Myklebust, R., Pascal, C., Sand, M., Solheim, D. \& Usov, S. 2010: New aeromagnetic and gravity compilations from Norway and adjacent areas; methods and applications. Petroleum Geology Conference Proceedings 7, 559-586. https://doi.org/10.1144/0070559.

Roberts, D., Heldal, T. \& Melezhik, V. 2001: Tectonic structural features of the Fauske conglomerates in the Lovgavlen Quarry, Nordland, Norwegian Caledonides, and regional implications. Norsk Geologisk Tidsskrift 81, 245-256.

Roberts, D., Melezhik, V.A. \& Heldal, T. 2002: Carbonate formations and early NW-directed thrusting in the highest allochthons of the Norwegian Caledonides: evidence of a Laurentian ancestry. Journal of the Geological Society, London 159, 117-120. https://doi.org/10.1144/0016-764901-128.

Skoglund, R.O. \& Lauritzen, S.-E. 2010: Morphology and speleogenesis of Okshola, Fauske, Northern Norway; example of a multi-stage network cave in a glacial landscape. Norwegian Journal of Geology 90, 123-139.

Styles, P., McGrath, R., Thomas, E. \& Cassidy, N.J. 2005: The use of microgravity for cavity characterization in karstic terrains. Quarterly Journal of Engineering Geology and Hydrogeology 38, 155-169. https://doi.org/10.1144/1470-9236/04-035.

Valen, V., Lauritzen, S.-E. \& Løvlie, R. 1997: Sedimentation in a highlatitude karst cave: Sirijordgrotta, Nordland, Norway. Norsk Geologisk Tidsskrift 77, 233-250. 